\title{
Divergent Aging Characteristics in CBA/J and CBA/CaJ Mouse Cochleae
}

\author{
Kevin K. Ohlemiller ${ }^{1,2}$, Ashley R. Dahl ${ }^{1}$, and Patricia M. Gagnon ${ }^{2}$ \\ ${ }^{1}$ Program in Audiology and Communication Sciences, Washington University School of Medicine, St. Louis, MO 63110, USA \\ ${ }^{2}$ Fay and Carl Simons Center for Biology of Hearing and Deafness, Department of Otolaryngology, Washington University School of \\ Medicine, 660 S. Euclid, St. Louis, MO 63110, USA
}

Received: 2 June 2010; Accepted: 21 July 2010; Online publication: 13 August 2010

\begin{abstract}
Two inbred mouse strains, CBA/J and CBA/CaJ, have been used nearly interchangeably as 'good hearing' standards for research in hearing and deafness. We recently reported, however, that these two strains diverge after 1 year of age, such that CBA/CaJ mice show more rapid elevation of compound action potential (CAP) thresholds at high frequencies (Ohlemiller, Brain Res. 1277: 70-83, 2009). One contributor is progressive decline in endocochlear potential (EP) that appears only in CBA/CaJ. Here, we explore the cellular bases of threshold and EP disparities in old CBA/J and $\mathrm{CBA} / \mathrm{CaJ}$ mice. Among the major findings, both strains exhibit a characteristic age $(\sim 18$ months in $\mathrm{CBA} / \mathrm{J}$ and 24 months in CBA/CaJ) when females overtake males in sensitivity decline. Strain differences in progression of hearing loss are not due to greater hair cell loss in CBA/ $\mathrm{CaJ}$, but instead appear to reflect greater neuronal loss, plus more pronounced changes in the lateral wall, leading to EP decline. While both male and female CBA/CaJ show these pathologies, they are more pronounced in females. A novel feature that differed sharply by strain was moderate loss of outer sulcus cells (or 'root' cells) in spiral ligament of the upper basal turn in old CBA/CaJ mice, giving rise to deep indentations and void spaces in the ligament. We conclude that $\mathrm{CBA} / \mathrm{CaJ}$ mice differ both quantitatively and qualitatively from $\mathrm{CBA} / \mathrm{J}$ in age-related cochlear pathology, and model different types of presbycusis.
\end{abstract}

Correspondence to: Kevin K. Ohlemiller - Fay and Carl Simons Center for Biology of Hearing and Deafness, Department of Otolaryngology · Washington University School of Medicine - 660 S. Euclid, St. Louis, MO 63110, USA. Telephone: +1-314-7477179; fax: +1-314-7477230; email: kohlemiller@wustl.edu
Keywords: presbycusis, stria vascularis, spiral ligament, endocochlear potential, hair cells, outer sulcus cells, marginal cells, gender effects, spiral ganglion

\section{INTRODUCTION}

Age-related hearing loss is the major form of hearing loss and the single predominant neurodegenerative disease of aging (Schacht and Hawkins 2005; Ohlemiller and Frisina 2008; Frisina 2009; Schmiedt 2010). Assessments of human temporal bones have led to a general framework whereby three key inner ear components (hair cells, neurons, and strial cells) are taken to degenerate independently in a manner that reflects environmental and genetic risk factors that may be unique to each (Schuknecht 1974; Schuknecht and Gacek 1993). An individual may show hearing loss that principally reflects accelerated loss of hair cells (sensory presbycusis), loss of neurons (neural presbycusis), loss of strial cells with attendant endocochlear potential (EP) decline (strial presbycusis) - or some combination of these. Understanding of the interdependency of cochlear cell types for survival, along with shared risk factors by cell type, has benefited from the application of inbred mouse strains exhibiting very different aging characteristics. Many inbred and genetically engineered mutant lines usefully model specific aspects of human presbycusis (Willott 1991; Henry and McGinn 1992; Willott 2001; Ohlemiller 2006), and have helped clarify principles learned from other animals (Covell and Rogers 1957; Bohne et al. 1990; Tarnowski et al. 1991; Spicer and Schulte 2005a). As part of this process, inbred strains showing rapid progressive hearing loss 
such as C57BL/6 (B6) or BALB/c have typically been compared with a few 'good hearing' standard strains, most often CBA/J or CBA/CaJ (collectively 'CBA'; e.g., Henry 1983; e.g., Erway et al. 1993; Hequembourg and Liberman 2001; Henry 2004). Both these strains hear well to at least 1 year of age, and have been used nearly interchangeably, or even mixed in the same studies. In fact, they diverged genetically over 80 years ago, and their genomes differ by more than 2,200 single-nucleotide polymorphisms (Bult et al. 2008). We recently reported that $\mathrm{CBA} / \mathrm{J}$ appear much more vulnerable to noise in the first months of life (Fernandez et al. 2010). Moreover, after 1 year of age $\mathrm{CBA} / \mathrm{CaJ}$ show more rapid hearing loss, in part due to EP decline that does not occur in CBA/J (Ohlemiller 2009). Here, we explore the cellular bases of threshold differences in old CBA/J and $\mathrm{CBA} / \mathrm{CaJ}$. As in a previous comparison of aging $\mathrm{B} 6$ and BALB/c mice (Ohlemiller et al. 2006), our strategy was to use $\mathrm{CBA} / \mathrm{J}$ mice to indicate which age-related pathology has no impact on EP maintenance, and the pathology that is magnified in $\mathrm{CBA} / \mathrm{CaJ}$ to indicate which changes are important for EP maintenance. We show here that these two strains model different forms of presbycusis. While $\mathrm{CBA} / \mathrm{J}$ most closely model 'uncomplicated' sensory presbycusis (Sha et al. 2008), CBA/CaJ adds aspects of strial and neural presbycusis. These are more pronounced in females, suggesting potentially hormonally related mechanisms of loss in two distinct cell populations. We also report novel loss of outer sulcus cells (or 'root' cells) in spiral ligament of $\mathrm{CBA} / \mathrm{CaJ}$ that presently appears unique to this strain.

\section{MATERIALS AND METHODS}

\section{Animals}

All procedures were approved by the Washington University Institutional Animal Care and Use Committee. Mice examined were offspring no more than five generations removed from $\mathrm{CBA} / \mathrm{J}$ and $\mathrm{CBA} / \mathrm{CaJ}$ breeders purchased from The Jackson Laboratory (JAX). The total sample included $105 \mathrm{CBA} / \mathrm{J}$ mice ranging in age from 2-27 months, and $124 \mathrm{CBA} /$ CaJ mice ranging in age from 2-34 months. Differences in maximum age examined reflect life span differences in the two strains, reportedly ranging 21-25 months in CBA/J and 24-29 months in CBA/CaJ (Fox et al. 1997). Samples were mixed by gender. Sample gender composition by data type is given in relevant sections.

\section{CAP recording}

Compound action potential (CAP) recordings were obtained from the left ear of $105 \mathrm{CBA} / \mathrm{J}$ and 124 $\mathrm{CBA} / \mathrm{CaJ}$ mice. Animals were anesthetized $(60 \mathrm{mg} / \mathrm{kg}$ sodium pentobarbital, IP) and positioned ventrally in a custom headholder. Core temperature was maintained at $37.5 \pm 1.0^{\circ} \mathrm{C}$ using a thermostatically controlled heating pad in conjunction with a rectal probe (Yellow Springs Instruments Model 73A). An incision was made along the midline of the neck and soft tissues were blunt dissected and displaced laterally to expose the trachea and animal's left bulla. A tracheostomy was then made and the musculature over the bulla was cut posteriorly to expose the bone overlying the round window. Using a hand drill, a small hole was made over the round window. The recording electrode consisted of a fine silver wire coated in plastic except at the tip, which had been melted into a ball that could be inserted into round window antrum. Additional silver electrodes inserted into the neck musculature and hind leg served as reference and ground, respectively. Electrodes were led to a Grass P15 differential amplifier $(100-3,000 \mathrm{~Hz}, \times 100)$, then to a custom amplifier providing another $\times 1,000$ gain, then digitized at $30 \mathrm{kHz}$ using a Cambridge Electronic Design Micro1401 in conjunction with SIGNAL ${ }^{\text {TM }}$ and custom signal averaging software operating on a $120 \mathrm{MHz}$ Pentium PC. Sinewave stimuli generated by a Hewlett Packard 3325A oscillator were shaped by a custom electronic switch to $5 \mathrm{~ms}$ total duration, including $1 \mathrm{~ms}$ rise/fall times. The stimulus was amplified by a Crown D150A power amplifier and output to an Alpine SPS-OEOA coaxial speaker located $10 \mathrm{~cm}$ directly lateral to the left ear. Stimuli were presented freefield and calibrated using a B\&K $41351 / 4$ in. microphone placed where the external auditory meatus would normally be. Toneburst stimuli at each frequency and level were presented 100 times at $3 / \mathrm{s}$. The minimum sound pressure level required for visual detection of a response $\left(\mathrm{N}_{1}\right)$ was determined at 2.5, 5, 10, 20, 28.3, 40, and $56.6 \mathrm{kHz}$, using a $5 \mathrm{~dB}$ minimum step size.

\section{Endocochlear potential recording}

The EP was measured immediately after CAP recording in $89 \mathrm{CBA} / \mathrm{J}$ and $104 \mathrm{CBA} / \mathrm{CaJ}$ mice. Using a fine drill, a hole was made in the left cochlear capsule directly over scala media of the lower basal turn. Apical turn EPs were also measured in 68 $\mathrm{CBA} / \mathrm{J}$ and $89 \mathrm{CBA} / \mathrm{CaJ}$ mice. Glass capillary pipettes (40-80 $\mathrm{M} \Omega$ ) filled with $0.15 \mathrm{M} \mathrm{KCl}$ were mounted on a hydraulic microdrive (Frederick Haer) and advanced until a stable positive potential was observed that did not change with increased electrode depth. The signal from the recording electrode was led to an AM Systems Model 1600 intracellular amplifier. 
Tissue processing and sectioning

At the end of recording, animals were overdosed and perfused transcardially with cold $2.0 \%$ paraformaldehyde $/ 2.0 \%$ glutaraldehyde in $0.1 \mathrm{M}$ phosphate buffer ( $\mathrm{pH}$ 7.4). Each cochlea was rapidly isolated, immersed in the same fixative, and the stapes was immediately removed. Complete infiltration of the cochlea by fixative was ensured by making a small hole at the apex of the cochlear capsule, and gently circulating the fixative over the cochlea using a transfer pipet. After decalcification in sodium EDTA for 72 hours, cochleas were post-fixed in buffered $1 \%$ osmium tetroxide, dehydrated in an ascending acetone series, and embedded in Epon. Left cochleas were sectioned in the mid-modiolar plane at $4.0 \mu \mathrm{m}$, then stained with toluidine blue for bright field viewing with a Nikon Optiphot ${ }^{\mathrm{TM}}$ light microscope using a $100 \times$ oil objective and a calibrated grid ocular. Typically, 50 sections were obtained from each cochlea, spanning $200 \mu \mathrm{m}$ centered on the modiolar 'core'.

\section{Morphometric analysis of mid-modiolar sections}

For quantitative histologic evaluation by age and strain, cochleas were taken from 'young' (2-4 months) and 'old' (19-27 months) mixed-gender samples in each strain. 'Young' samples included eight $\mathrm{CBA} / \mathrm{J}$ and 6 $\mathrm{CBA} / \mathrm{CaJ}$ mice; 'Old' samples included $12 \mathrm{CBA} / \mathrm{J}$ and $13 \mathrm{CBA} / \mathrm{CaJ}$. An additional 'very old' CBA/CaJ sample (28-34 months, $n=9$ ) was evaluated for comparison with other $\mathrm{CBA} / \mathrm{CaJ}$, but could not be compared directly with $\mathrm{CBA} / \mathrm{J}$ due to differences in lifespan. For each animal, five mid-modiolar sections distributed evenly over the $200-\mu \mathrm{m}$ sectioned distance were analyzed by an observer blinded to strain and age. Strial and ligament measures were chosen from previous studies (Ohlemiller and Gagnon 2004a; Ohlemiller et al. 2006, 2008, 2009; Ohlemiller and Gagnon 2007), and included strial thickness, marginal cell density, intermediate cell density, basal cell density, strial capillary density, ligament thickness, density in ligament of types I, II, and IV fibrocytes, and the appearance of outer sulcus cells. Based on preliminary observations of anomalies in the outer sulcus cell region of spiral ligament in old CBA/CaJ, two additional metrics were devised as described below. DIC images used for illustration were obtained on a Zeiss LSM 700 laser scanning confocal microscope using ZEN ${ }^{\mathrm{TM}}$ software, then further processed using CANVAS ${ }^{\mathrm{TM}}$.

\section{Neurons}

Estimates of spiral ganglion cell density were obtained in the cochlear lower basal turn, upper basal turn, and apical turn. Neuronal density was estimated by counting nucleated neuronal profiles within a 3,600$\mu \mathrm{m}^{2}$ grid roughly centered on Rosenthal's canal at each location.

\section{Stria vascularis}

Strial thickness was measured orthogonal to the midpoint in the lower base, upper base, and lower apex. Only nucleated profiles were included in strial cell counts. Because marginal cell density was of special interest among strial cell types, marginal cells were counted in the lower base, upper base, and lower apex, while other cell types were quantified only in the upper base. Marginal cells, intermediate cells, and basal cells were counted in an $80-\mu \mathrm{m}$ linear segment of stria centered at the midpoint. No attempt was made to distinguish between lower and upper level intermediate cells, a distinction made by Spicer and Schulte (2005b). Unconnected capillary profiles were counted over the entire strial profile in the lower base, upper base, and lower apex (Fig. 13A). In a separate analysis (see Figs. 13B, C and 15C, F), capillaries were counted coincident with other strial cell counts in an $80 \mu \mathrm{m}$ linear segment of stria in the upper base, and the luminal diameters of those capillaries were measured.

\section{Spiral ligament}

Ligament thickness was measured in the lower base, upper base, and lower apex. At each location, thickness was measured on an axis co-linear with the strial midline (coaxial with strial thickness measures). Types I, II, and IV fibrocytes were assessed in the upper base using a $1,600 \mu \mathrm{m}^{2}$ area. These were identified based on location, an approach taken in previous studies (Hequembourg and Liberman 2001; Hirose and Liberman 2003; Lang et al. 2003). Only nucleated profiles were included.

\section{Outer sulcus cells/root cells}

OSCs were easily recognizable by light staining of their cytoplasm, and by their large, lightly stained, either circular or ovoid nuclei (Fig. 17; Duvall 1969; Spicer et al. 1996). These cells line the ligament wall between Claudius cells and spiral prominence epithelial cells, and are thought to be involved in spatial buffering and recirculation of $\mathrm{K}^{+}$and $\mathrm{Na}^{+}$(Marcus and Chiba 1999; Jagger et al. 2010). Depending on location, they may either directly border scala media, or be covered by Claudius and spiral prominence cells. Similar-appearing cells compose distinct 'roots' or 'pegs' (Duvall 1969) that do not border scala media, and project deep into the ligament. Each root is usually composed of multiple cells. It is presently not clear whether OSCs and root cells are biochemically or 
functionally distinct, and it is also possible that different basal/apical locations and even different superior/ inferior positions in the ligament contain distinct types of these (Jagger et al. 2010). For present purposes, references to OSCs should be understood to include root cells. We noted that OSCs bordering scala media and those composing roots were often missing in old $\mathrm{CBA} / \mathrm{CaJ}$ and devised two metrics to facilitate quantitative analysis. For the first metric, OSC nuclei were counted over the entire ligament profile in upper and lower basal turn. For the second metric, each section was blindly scored 'present' or 'absent' for obvious indentations or voids in the region where OSCs are normally observed. To ensure that empty capillary profiles were not scored as voids, apparent voids were always examined using a $\times 100$ oil objective for an endothelial cell lining.

\section{Hair cell counts}

Right cochleas of eight old CBA/J and eight old CBA/ CaJ mice were dissected using fine blades into halfturn segments, immersed in mineral oil in a depression slide, and examined as surface preparations by Nomarski optics using a $\times 20$ oil objective and a calibrated grid ocular. The percent outer hair cells (OHCs) and inner hair cells (IHCs) missing (as judged by the absence of nuclei) was estimated in contiguous $200 \mu \mathrm{m}$ segments, and data were recorded separately by cell type as a function of distance from the basal tip. For each hair cell type, cochlear distance versus percent present was plotted as a function of frequency based on Muller et al. (2005).

\section{Statistical analysis}

CAP thresholds were analyzed for each age group by two-way ANOVA (threshold $\times$ strain, frequency; SIGMASTAT $\left.^{\mathrm{TM}}\right)$. OHC and IHC counts were separately analyzed by two-way ANOVA (percent present $\times$ strain, location). For other histologic metrics, estimates in each animal were averaged to yield an overall mean for that animal. Strial and ligament metrics obtained for more than one cochlear location (ganglion cell density, strial thickness, marginal cell density, strial capillary density, ligament thickness, OSC density) were analyzed by two-way ANOVA (metric $\times$ group, location). Metrics obtained only for the upper base were analyzed by one-way ANOVA. All ANOVAs were followed by Bonferroni multiple comparisons tests. Non-parametric data (presence versus absence of indentations or voids in ligament) were analyzed by $Z$ test. For some analyses, linear or nonlinear regression was applied (SIGMASTAT ${ }^{\mathrm{TM}}$ ). For all tests, $p<0.05$ was taken to denote a significant difference between groups, or regression slope significantly different from zero.

\section{RESULTS}

\section{CAP thresholds}

At 1 year of age CAP thresholds were little changed from those in young mice (not shown), and showed no effect of strain (Fig. 1A). By 17-19 months, however, thresholds at $20 \mathrm{kHz}$ and higher significantly differed by strain, with $\mathrm{CBA} / \mathrm{CaJ}$ exhibiting poorer thresholds (Fig. 1B). Strain differences at high frequencies were further magnified at 22-26 months (Fig. 1C). Both strains showed similar hearing decline below $10 \mathrm{kHz}$.

Based on differences by strain in CAP audiograms, two frequencies were chosen for more detailed analysis by strain, age, and gender. Five kilohertz was selected as a low frequency where both strains indicated similar age trajectories, and $28.3 \mathrm{kHz}$ was selected as high frequency where strain differences appeared maximal. Separate scatter plots by gender and frequency in Figure 2 compare CBA/J and CBA/ CaJ explore trends across all animals. Second-order polynomials have been fit to each group to aid in extracting trends. Although male CBA/J are reported to live longer than females (Fox et al. 1997), our sample favored females after 18 months, rendering gender comparisons at advanced ages tentative. Both male and female CBA/J showed some threshold elevation at $5 \mathrm{kHz}$ after about 10 months of age, accelerating by 17 months (Fig. 2A, B). Sensitivity at $28.3 \mathrm{kHz}$ in $\mathrm{CBA} / \mathrm{J}$ appeared better preserved with age than at $5 \mathrm{kHz}$, although females showed accelerated loss by 17 months (Fig. 2C, D). Threshold trends in $\mathrm{CBA} / \mathrm{CaJ}$ were similar to those in $\mathrm{CBA} / \mathrm{J}$ at $5 \mathrm{kHz}$ (Fig. 2A, B), with both males and females indicating accelerated CAP threshold shifts by $16-$ 18 months of age. The rate of threshold elevation at $28.3 \mathrm{kHz}$, however, featured a much stronger gender dependence than in CBA/J (Fig. 2C, D), with males showing a nearly linear progression, compared to a clear acceleration in females by 24 months. Figure 3 compares just the fitted polynomials. Again, different age endpoints reflect the fact that both male and female $\mathrm{CBA} / \mathrm{CaJ}$ mice in our sample lived up to 9 months longer than CBA/Js. While little difference is apparent by strain or gender at $5 \mathrm{kHz}$, at $28.3 \mathrm{kHz}$, both strains show similar gender-based trends in overall threshold trajectory. In each case, there appears to be an age where a tendency for better hearing in females gives way to better hearing in males. This age, roughly 18 months in $\mathrm{CBA} / \mathrm{J}$, and 24 months in $\mathrm{CBA} / \mathrm{CaJ}$ is marked by accelerated threshold elevation in females. The acceleration in 

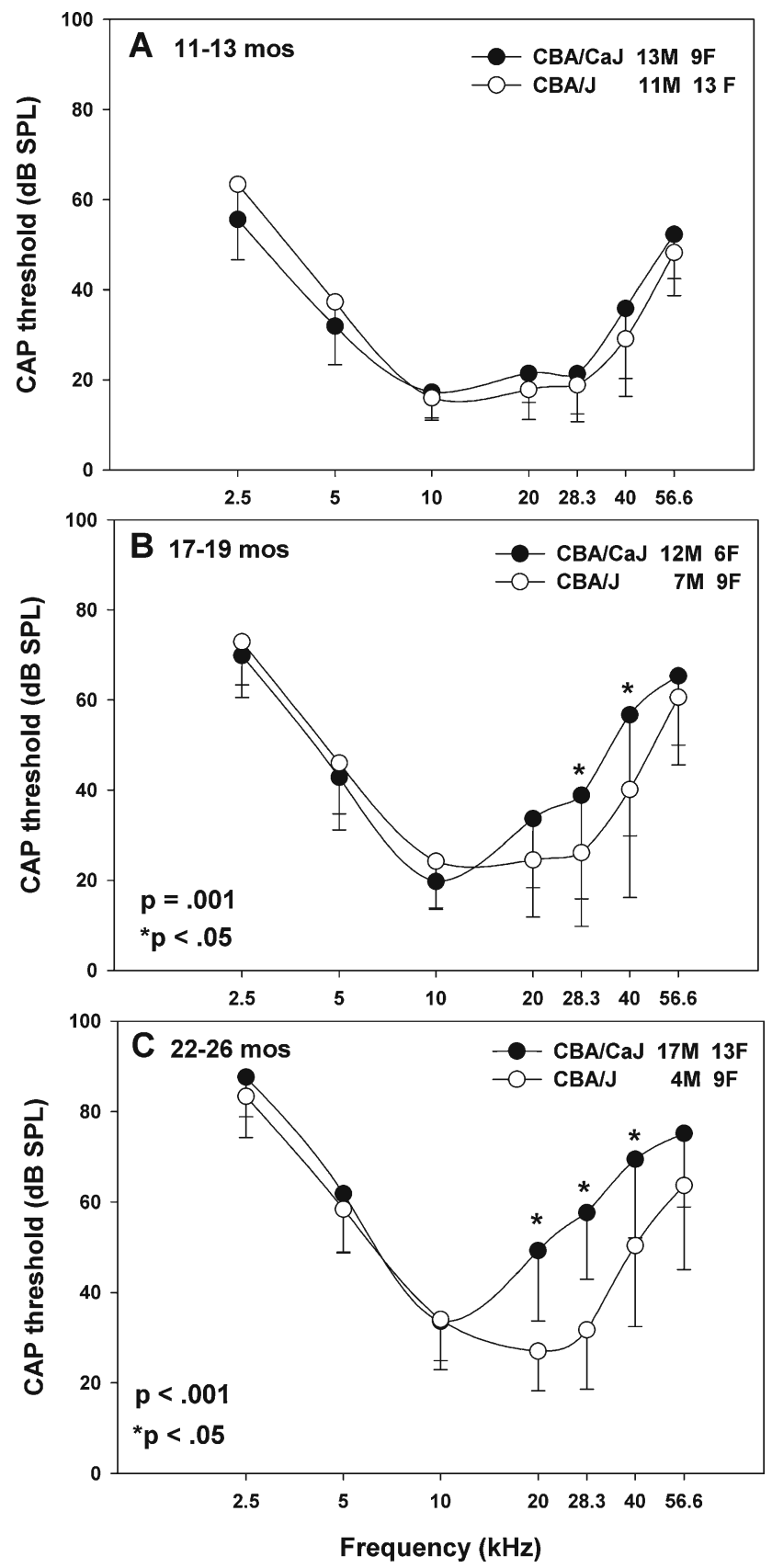

FIG. 1. A-C Mean (-SD) CAP thresholds for $C B A / J$ and $C B A / C a J$ mice in three different age ranges. Sample size and gender composition of each sample is given in each graph. CBA/CaJ mice show significantly higher thresholds at $20 \mathrm{kHz}$ and above by 1719 months (B). *Bonferroni multiple comparisons.

female CBA/CaJ, however, appears much sharper than in $\mathrm{CBA} / \mathrm{J}$.

\section{Hair cell loss}

To determine the bases of threshold differences by strain and gender, we first performed hair cell counts in old mice of both strains. As shown in Figure 4, inner hair cell losses in both strains were similarly modest and limited to the extreme base and apex. Since young $\mathrm{CBA} / \mathrm{J}$ and $\mathrm{CBA} / \mathrm{CaJ}$ mice show little hair cell loss (Spongr et al. 1997), the losses indicated by our counts presumably are strictly age-associated. For both strains, outer hair cells were completely preserved only in the upper base $(\sim 15-25 \mathrm{kHz}$ region), so that progressive threshold elevation at both low and high frequencies appeared explainable in part by outer hair cell loss or dysfunction. Outer hair cell loss differed significantly by strain. Notably, however, the trend actually favored CBA/CaJ mice (for example see OHC profiles in Fig. 6 inset), so that CAP threshold differences by strain could not be accounted for in terms of hair cell survival. While no gender effects were detected, samples by gender were too small to rule out an effect.

\section{Spiral ganglion cell loss}

Young mice of each strain showed similar, relatively flat, neuronal density functions by location (Fig. 5A). With age, both strains showed clear loss of neurons. However, the extent of loss was significantly greater in $\mathrm{CBA} / \mathrm{CaJ}$ than in $\mathrm{CBA} / \mathrm{J}$, particularly in the apex and lower base (see example in Fig. 6). Losses in the lower base for $\mathrm{CBA} / \mathrm{CaJ}$ mice exceeded $50 \%$ on average, compared to about $20 \%$ in CBA/J. Neuronal losses in $\mathrm{CBA} / \mathrm{CaJ}$ appeared worse overall in females (Fig. 5B), although a significant difference was detected only in the upper cochlear base.

\section{$\mathrm{EP}$ reduction in old $\mathrm{CBA} / \mathrm{CaJ}$}

We previously showed that $\mathrm{CBA} / \mathrm{CaJ}$ mice tend toward age-related EP decline, while CBA/J do not (Ohlemiller 2009). Figure 7, excerpted from the previous report, summarizes this result. Again, data in $\mathrm{CBA} / \mathrm{J}$ are restricted to approximately the first 2 years of life, reflecting the shorter lifespan of these mice. Nevertheless, the relation between EPs and age is virtually flat in $\mathrm{CBA} / \mathrm{J}$, compared to a significant negative regression slope in CBA/CaJ. Three features completely absent in $\mathrm{CBA} / \mathrm{J}$ demarcate the age versus EP trajectory in CBA/ CaJ. First, the incidence of EPs below $\sim 95 \mathrm{mV}$ versus age is highly variable. The earliest clearly low values appear around 1 year of age, but then occur probabilistically at all later ages. There is no progressive downward shift of all EPs. Only after 30 months of age did we find no EPs above $100 \mathrm{mV}$ in these mice. Second, also beginning around 1 year of age, the upper limit of the EP distribution in CBA/CaJ slightly decreases, leaving no cases where the EP is greater than $110 \mathrm{mV}$. Although this latter feature is subtle (see below), it can be described as a deterministic loss of the highest EPs after 1 year. Finally, it may be noted that most instances of clearly 

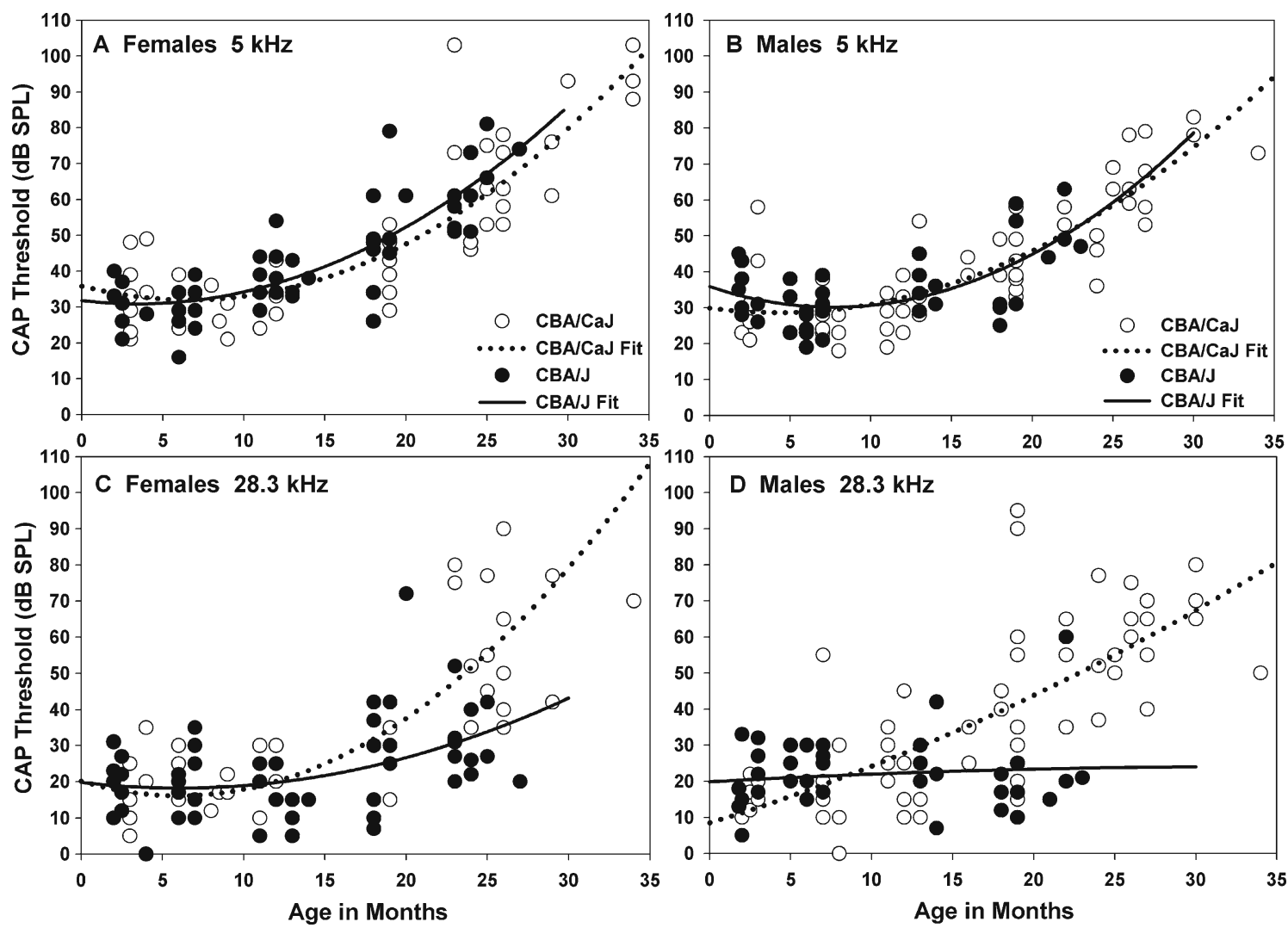

FIG. 2. Scatter plots of CAP threshold versus age in months at $5 \mathrm{kHz}(\mathbf{A}, \mathbf{B})$ and $28.3 \mathrm{kHz}(\mathbf{C}, \mathbf{D})$ for both $\mathrm{CBA} / \mathrm{J}$ and CBA/Ca) mice. Left and right columns separate animals by gender. Lines are fitted second-order polynomials. At $28.3 \mathrm{kHz}, \mathrm{CBA} / \mathrm{CaJ}$ exhibit more hearing loss with age than $\mathrm{CBA} / \mathrm{J}$, irrespective of gender.

reduced $\mathrm{EP}$ in old $\mathrm{CBA} / \mathrm{CaJ}$ mice appear in females, a point to which we return below.

We considered whether comparing EPs measured at only a single cochlear location was adequate to support broad claims of strain and age dependence. Since we had obtained EP measures from both base and apex in a number of mice, it was possible to compare basal and apical values, both when the EP remained normal and when it was depressed. The tight clustering of data in Figure 8A emphasizes the homogeneity of EPs in $\mathrm{CBA} / \mathrm{J}$ mice, irrespective of age. Consistent with previous estimates (Lang et al. 2002; Wu and Marcus 2003; Ohlemiller et al. 2006), the normal basal turn EP in mice averages about $10 \mathrm{mV}$ higher than in the apex. When the EP is depressed, as in some older CBA/CaJ mice (Fig. 8B), basal and apical turn EPs remain highly correlated. However, when the EP is depressed, the normal spatial gradient favoring the basal turn is eliminated and even reversed, leaving the EP slightly greater in the apex. In this regard, the effects of aging in CBA/ $\mathrm{CaJ}$ resemble those of noise in CBA-related strains (Ohlemiller and Gagnon 2007). From this analysis, we conclude that when the basal turn EP is depressed in the mouse, it is depressed to a similar degree all along the cochlear spiral.
We argued from Figure 7 that one feature distinguishing $\mathrm{CBA} / \mathrm{CaJ}$ from $\mathrm{CBA} / \mathrm{J}$ is that EPs greater than $\sim 110 \mathrm{mV}$ disappear in $\mathrm{CBA} / \mathrm{CaJ}$ after about 12 months of age. This trend is confirmed in Figure 9, which shows the distribution of EP values (grouped by $10 \mathrm{mV}$ bins) by strain and age group. While the distribution of EPs by strain is similar in younger mice (Fig. 9A, B), changes in the EP distribution after 12 months in $\mathrm{CBA} / \mathrm{CaJ}$ feature both skewing toward lower values and complete disappearance of EPs $>110 \mathrm{mV}$ (compare Fig. 9C, D). By contrast with $\mathrm{CBA} / \mathrm{CaJ}$, the distribution of EPs in old CBA/J appeared little affected by age. Notably, of 15 old CBA/CaJ mice showing EPs between 105 and $110 \mathrm{mV}, 14$ were male. Among young CBA/CaJs (Fig. 9A) males and females were equally likely to show an EP above $110 \mathrm{mV}$. Therefore, although both males and females exhibit EP decline at ages greater than 12 months, the decline is worse in females.

Figure $10 \mathrm{~A}$ confirms that old $\mathrm{CBA} / \mathrm{CaJ}$ mice showed lower EPs than CBA/J mice, although the overall difference was significant only in females. We next considered to what extent CAP threshold differences by strain could be accounted for by variation in EP. Figure 10B shows significant correlations between 

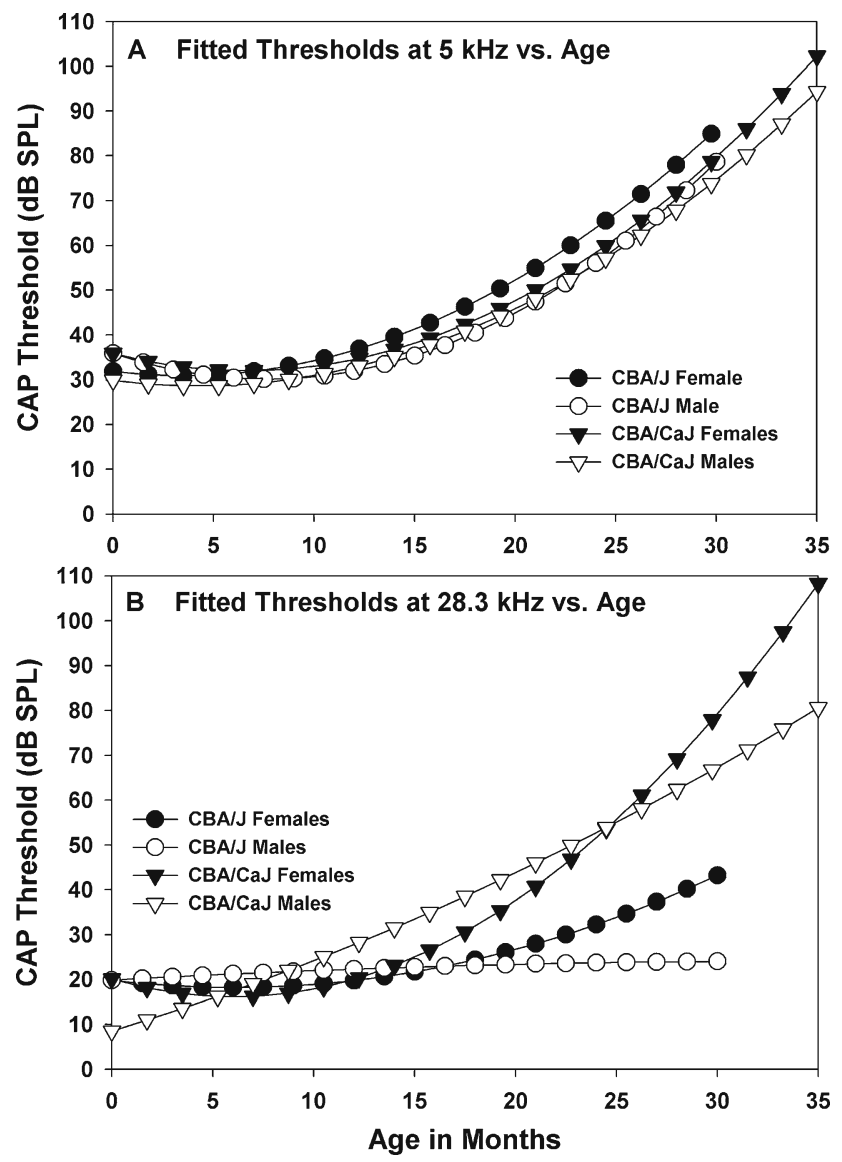

FIG. 3. Overlay of fitted polynomial functions from Figure 2. A and $\mathbf{B}$, respectively, superimpose fitted curves for both strains and genders for thresholds at 5 and $28.3 \mathrm{kHz}$.

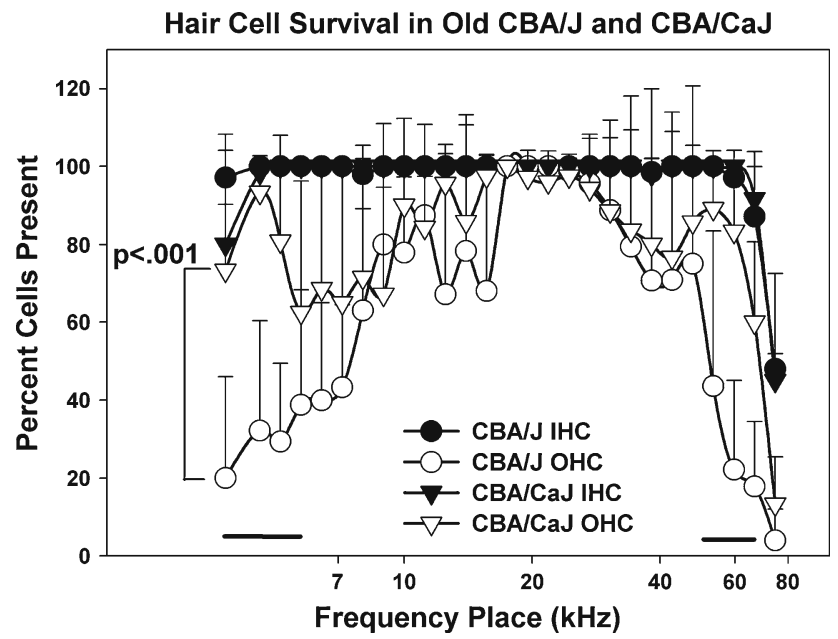

FIG. 4. Mean (+SD) inner and outer hair cell survival for old CBA/J (22-26 months; $n=8)$ and CBA/CaJ (23-27 months; $n=8)$ mice. Each group was roughly evenly split by gender. Frequency map is based on Muller et al. (2005). Outer hair cell survival differed significantly by strain and location, with $\mathrm{CBA} / \mathrm{CaJ}$ mice showing better $\mathrm{OHC}$ survival. Horizontal bars above the $X$ axis denote locations where differences were significant by Bonferroni multiple comparisons test.
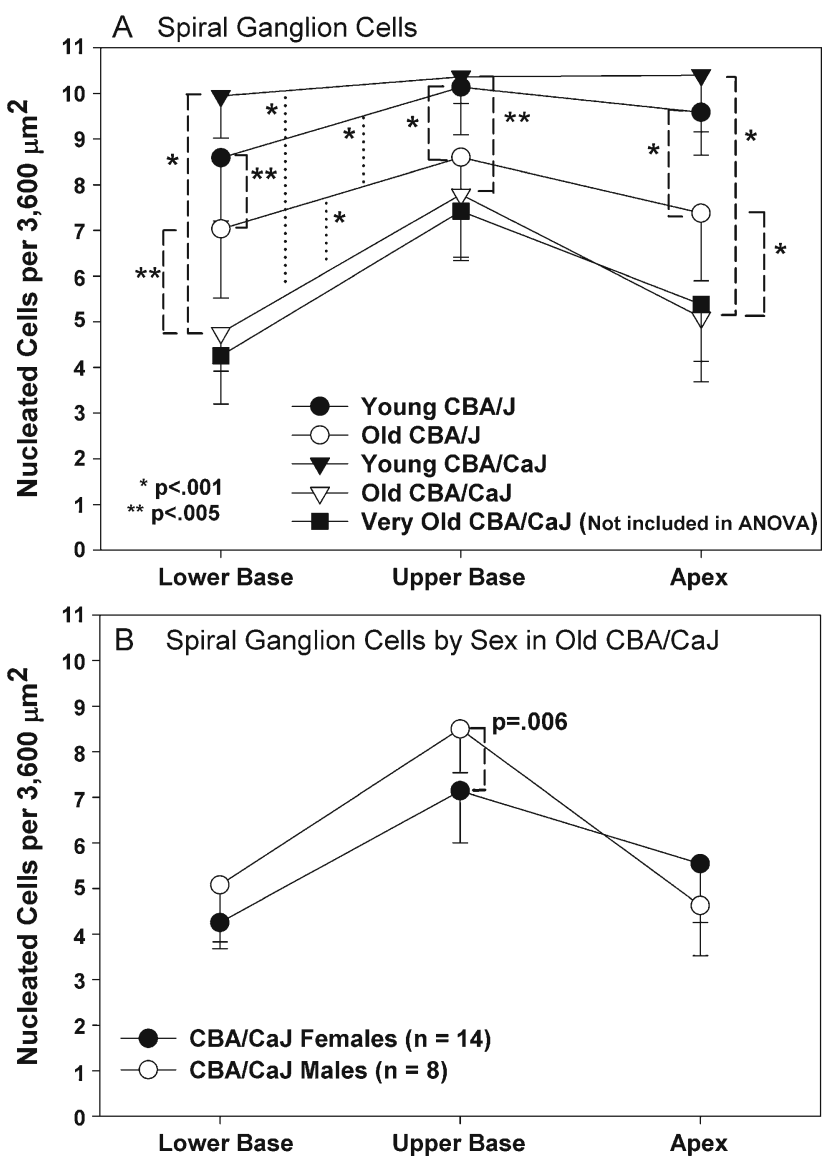

FIG. 5. Mean $(-S D)$ spiral ganglion cell density at three cochlear locations by strain and age (A), and for old male and female CBA/CaJ (B). Old CBA/Cal mice showed significantly greater neuronal loss, particularly in the apex and lower base. Old female CAB/Cal tended toward greater neuronal loss than males. In $\mathrm{B}$, data from 13 'old' and nine 'very old' $\mathrm{CBA} / \mathrm{Cal}$ mixed-gender data sets were combined. $P$ values are from Bonferroni multiple comparisons tests following two-way ANOVA.

CAP threshold at $28.3 \mathrm{kHz}$ and basal turn EP for both male and female CBA/CaJ. From $R^{2}$ estimates, roughly $30 \%$ of threshold variation in females and $15 \%$ of threshold variation in males could be accounted for by EP variation.

\section{Strial anatomic correlates of EP reduction}

Since variation in the EP could account in part for CAP threshold variation by strain, we considered what anatomic changes in the cochlear lateral wall are most closely associated with EP decline, and whether these changes also show gender dependence. We begin with the stria vascularis.

\section{Strial thickness}

Six examples in Figure 11 illustrate the variable appearance of the stria in upper basal turn of old $\mathrm{CBA} / \mathrm{CaJ}$ mice. The three examples associated with a low EP feature strial thinning (Fig. 11A), strial edema 


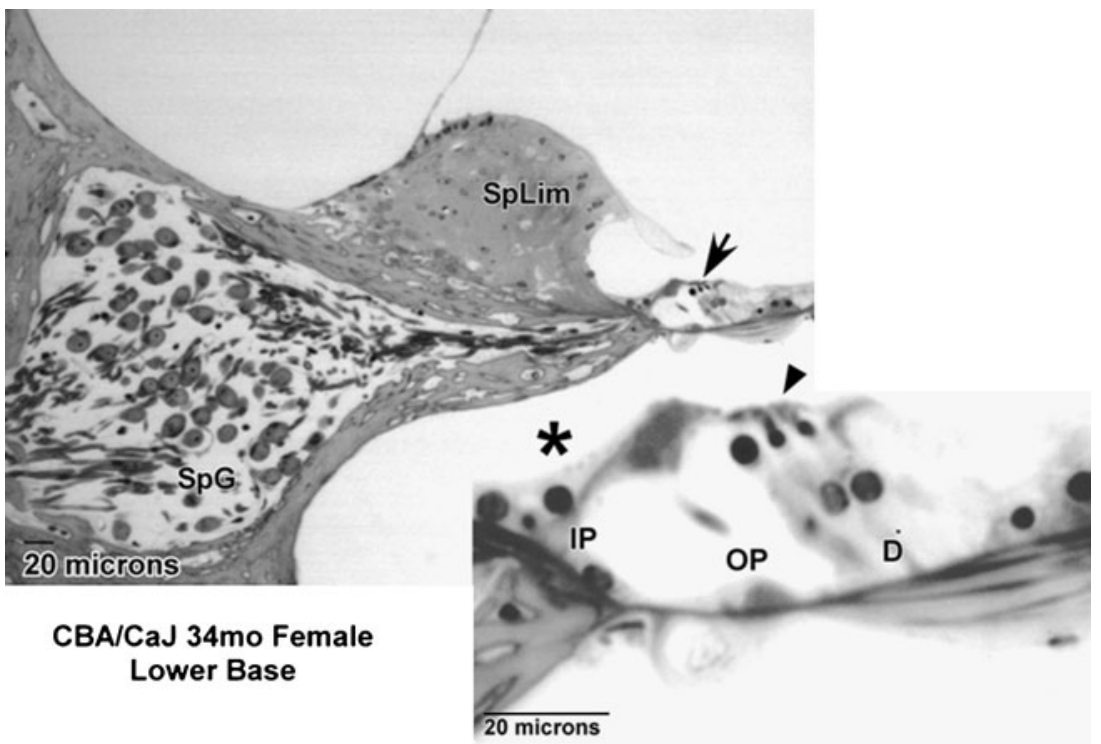

FIG. 6. Lower basal turn (mid-hook region) Rosenthal's canal and organ of Corti in an old female CBA/Cal mouse showing loss of spiral ganglion cells $(S p G)$. Inset shows expanded organ of Corti, calling attention to the presence of outer hair cells (arrowheads in both images), but the absence of inner hair cells (asterisk) in this animal. SpLim spiral limbus, IP inner pillar, $O P$ outer pillar, $D$ Deiters' cells.
(Fig. 11C), and a typical normal profile (Fig. 11F). Strial thinning with age is commonly described in humans and animals (Kusunoki et al. 2004; Suzuki et al. 2006; Ishiyama et al. 2007), and may reflect cell changes that lead to EP decline (Ohlemiller et al. 2008, 2009). Both $\mathrm{CBA} / \mathrm{J}$ and $\mathrm{CBA} / \mathrm{CaJ}$ showed significant strial thinning throughout most of the cochlea (Fig. 12). Counter to any simple prediction,
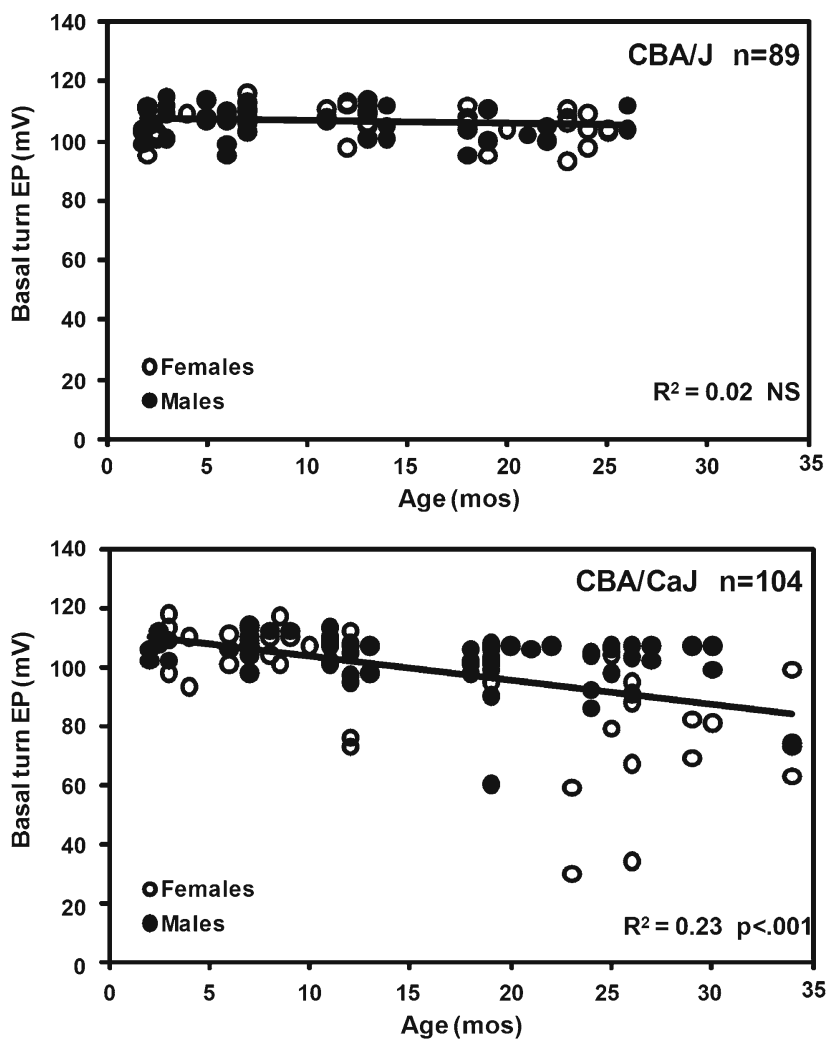

FIG. 7. Scatter plots of basal turn EP versus age for CBA/J (top) and CBA/Cal (bottom). Significant reduction (indicated by significant non-zero regression coefficient) is seen only in $\mathrm{CBA} / \mathrm{CaJ}$. Most of the mice with EPs below $95 \mathrm{mV}$ are female. however, it was $\mathrm{CBA} / \mathrm{J}$ that sustained the greatest degree of thinning on average. It is possible that cases of strial thinning were offset by instances of overt or subtle strial edema. Thus impaired strial function in old CBA/CaJ
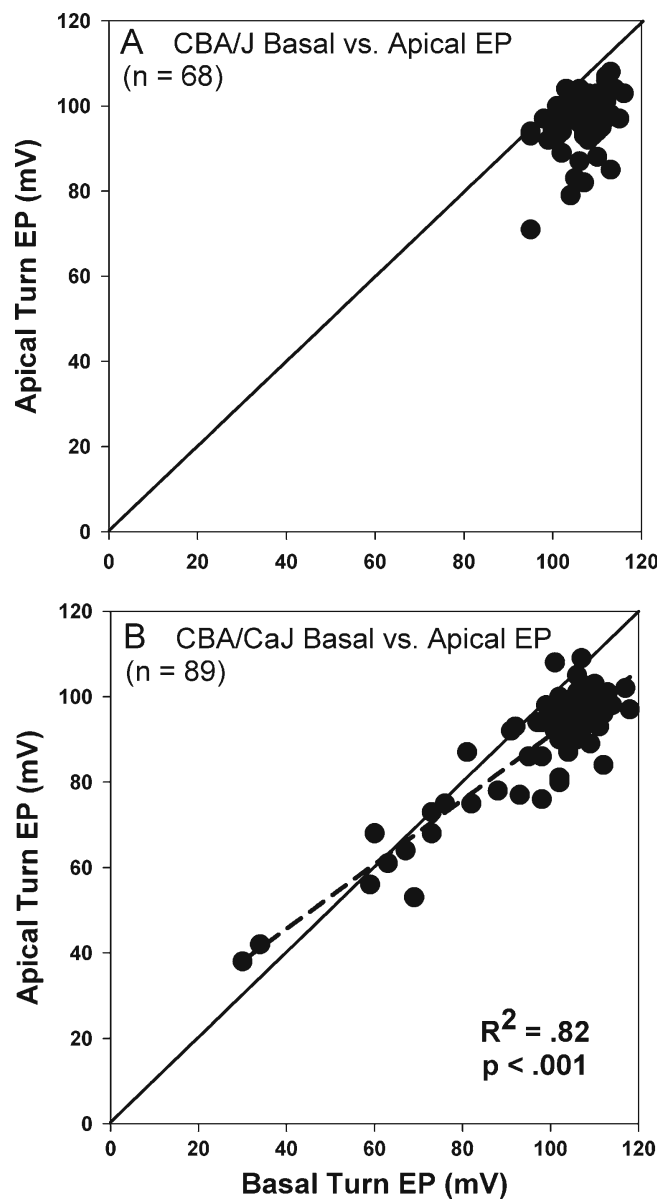

FIG. 8. Scatter plots of basal turn EP versus apical turn EP for CBA/J (A) and $\mathrm{CBA} / \mathrm{CaJ}$ (B) across all ages. Normal EP is $\sim 10 \mathrm{mV}$ higher in the base than in the apex. Significant EP reduction in CBA/CaJ is associated with reversal of the EP spatial gradient. 


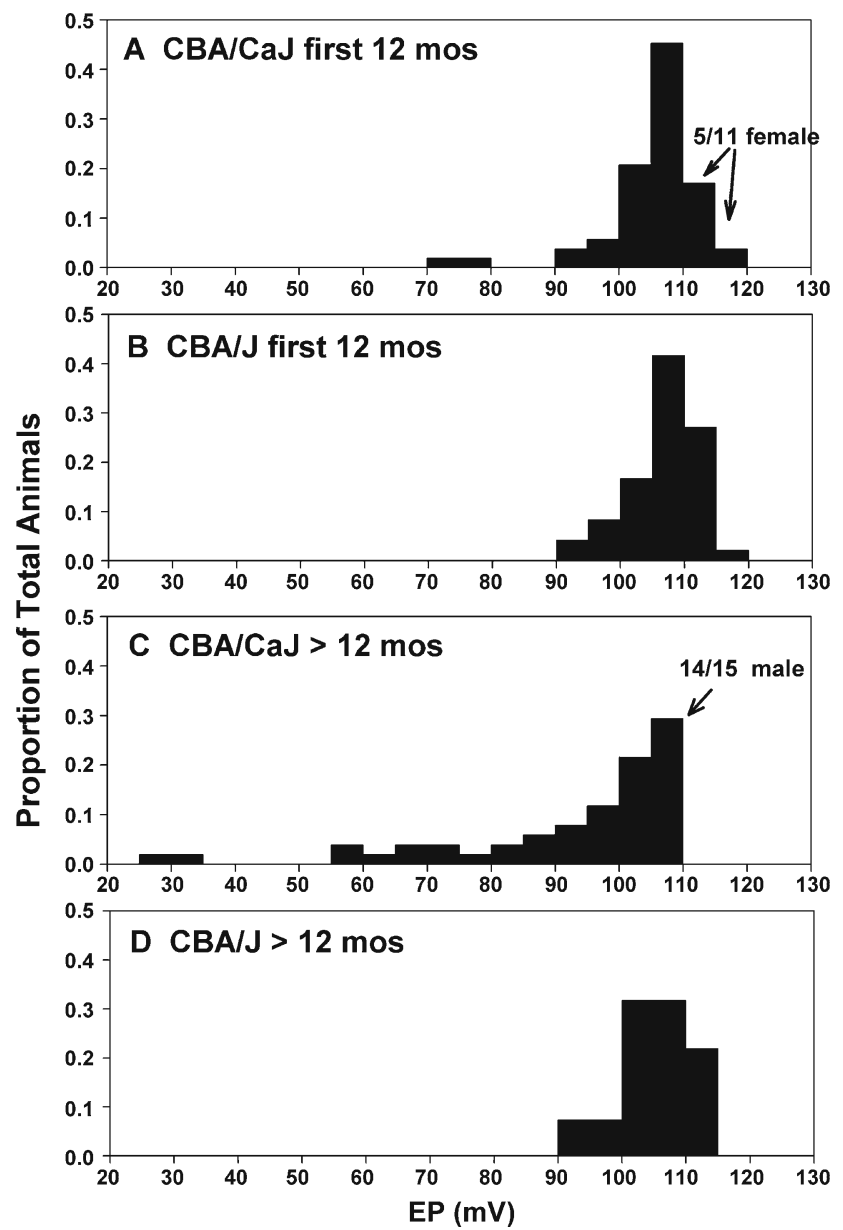

FIG. 9. Distribution of basal turn EPs plotted separately for $C B A / J$ and $\mathrm{CBA} / \mathrm{Ca}$ al mice during the first 12 months of life $(\mathbf{A}, \mathbf{B})$ versus later ages $(\mathbf{C}, \mathbf{D})$. Only older CBA/CAJ showed leftward skewing of EPs and dropout of females from EPs $>110 \mathrm{mV}$ (arrows). Bins are normalized to sample size by strain and age, so that each bin represents the proportion of animals with an EP in a given range.

mice did not reliably follow any one form of geometric change detectable at the light microscope level.

\section{Strial capillary density and size}

Strial capillary loss and thickening of capillary basement membranes have been suggested to underlie age-related EP decline (Gratton and Schulte 1995; Gratton et al. 1996; Thomopoulos et al. 1997). Although we did not measure strial capillary basement membrane thickness, old CBA/CaJ mice suggested no greater change in the appearance of capillary walls than did CBA/J. The examples in Figure 11 suggest a tendency toward greater capillary loss in cases when the EP is reduced (Fig. 11A, C), yet at the same time, a tendency for remaining capillaries become enlarged (Fig. 11F). Analysis of capillary density by strain, age, and location (Fig. 13A) revealed significant loss of capillaries with age only in $\mathrm{CBA} / \mathrm{CaJ}$, and significant differences between old $\mathrm{CBA} / \mathrm{J}$ and $\mathrm{CBA} / \mathrm{CaJ}$. Over- all, however, losses were less than $20 \%$ at any location, and capillary loss was not significantly correlated with EP (see Fig. 15C). No gender effects were found in $\mathrm{CBA} / \mathrm{CaJ}$ (not shown).

Mean strial capillary size did not vary significantly by strain, age, or gender (not shown). Instead we noted a tendency for capillary sizes to redistribute in old animals, and for the manner of the redistribution to vary by group. As shown in Figure 13B, young mice irrespective of strain have strial capillaries that are equally likely to show diameters of $1-5$ or $6-10 \mu \mathrm{m}$. In older mice, the proportion of capillaries with diameters of $6-10 \mu \mathrm{m}$ is reduced, and the majority of remaining capillaries show smaller diameters. However, as made clearer in Figure 13C, which shows changes in capillary size with age, old $\mathrm{CBA} / \mathrm{CaJ}$ mice retain a greater fraction of capillaries with diameters at least $6-10 \mu \mathrm{m}$

\section{A EP by sex in CBA/J and CBA/CaJ $>12$ mos old}

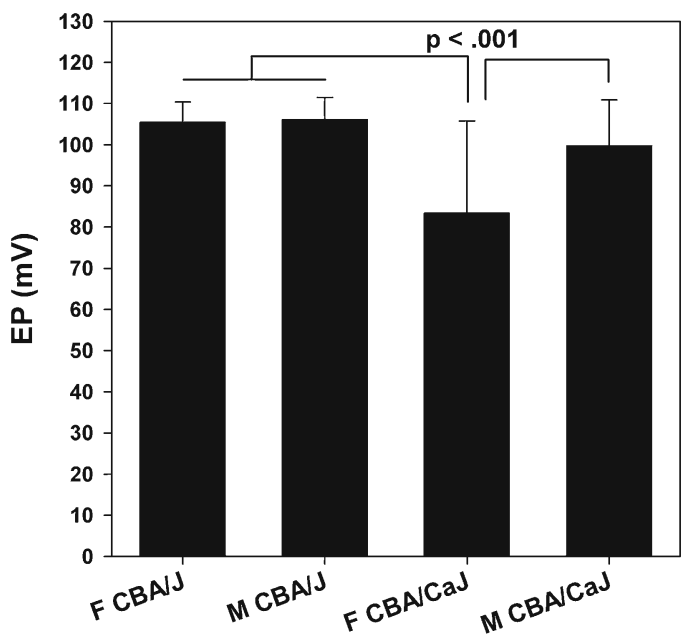

B CAP Threshold at $28.3 \mathrm{kHz}$ vs. EP in Old CBA/CaJ

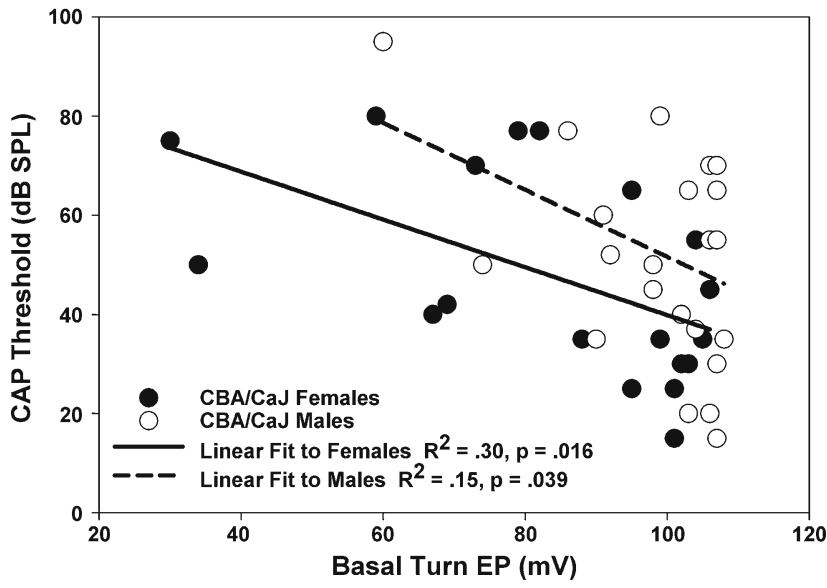

FIG. 10. A Mean $(+S D)$ basal turn EP by strain for animals $>12$ months old. Only old CBA/CaJ females differed significantly from other groups. B Basal turn EP versus CAP threshold at $28.3 \mathrm{kHz}$ plotted separately for all CBA/CaJ males and females. Significant correlations were found for each. $P$ values in A are from Bonferroni multiple comparisons tests following one-way ANOVA. 

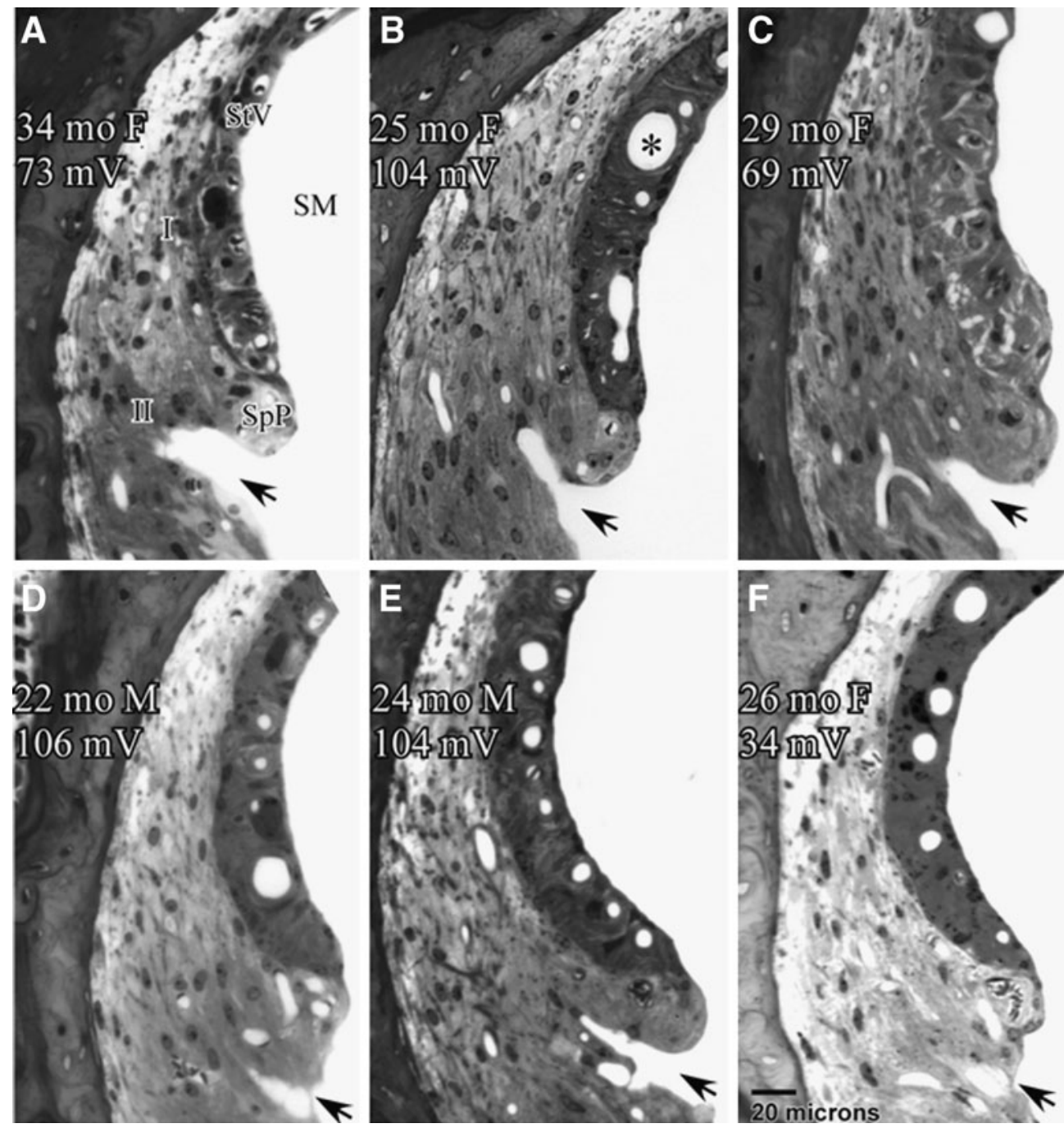

FIG. 11. A-F Example lateral wall of the cochlear upper basal turn in six old CBA/Cal mice with very different EPs. Age, gender, and EP are given in each panel. General features include a mainly normal appearance of the spiral ligament and a large degree of heterogeneity in the stria vascularis. The most glaring pathology of the lateral wall

is the apparent loss of outer sulcus cells/root cells in the region of spiral ligament just below spiral prominence (arrows). Asterisk in B highlights large capillaries that appeared most prominent in old female mice (see text). Labels in A denote major landmarks: StV stria vascularis, SM scala media, SpP spiral prominence, I and II types I and II fibrocytes.

in diameter. This trend is especially pronounced in old $\mathrm{CBA} / \mathrm{CaJ}$ females, in which $\sim 11 \%$ of strial capillaries are larger than $10 \mu \mathrm{m}$ (arrow in Fig. 13B). The old CBA/CaJ females show only a slight gain in the fraction of small capillaries, and uniquely, show a gain in the fraction of capillaries larger than $10 \mu \mathrm{m}$ (arrows in Fig. 13C). In summary, capillary data suggest that neither reduction in strial capillary density nor reduced capillary size account for EP decline in old CBA/CaJ. Instead, retention of larger capillaries-including an increase in the fraction of large capillaries in females - may signal other changes that are tied to EP reduction.

\section{Strial cell density}

Both human temporal bone studies (Schuknecht et al. 1974; Pauler et al. 1988; Schuknecht and Gacek
1993) and animal studies (Spicer and Schulte 2005a; Ohlemiller et al. 2006; Ohlemiller et al. 2009) have emphasized the frequent limiting nature of strial marginal cell survival and function in aging. Marginal cell counts in CBA/J and CBA/CaJ likewise suggested that marginal cell density distinguishes these strains both young and old. As shown in Figure 14, CBA/J mice may begin life with more marginal cells than $\mathrm{CBA} / \mathrm{CaJ}$, and then retain these over their normal life span, showing no significant reduction in number with age. By contrast, old $\mathrm{CBA} / \mathrm{CaJ}$ mice show an overall significant loss of marginal cells with age at all locations. Although no interactions with location were detected, marginal cell losses with age in $\mathrm{CBA} / \mathrm{CaJ}$ appeared greatest in the basal half of the cochlea. No significant effect of gender was detected (data not shown). Thus, differences in EP by sex in old CBA/ 


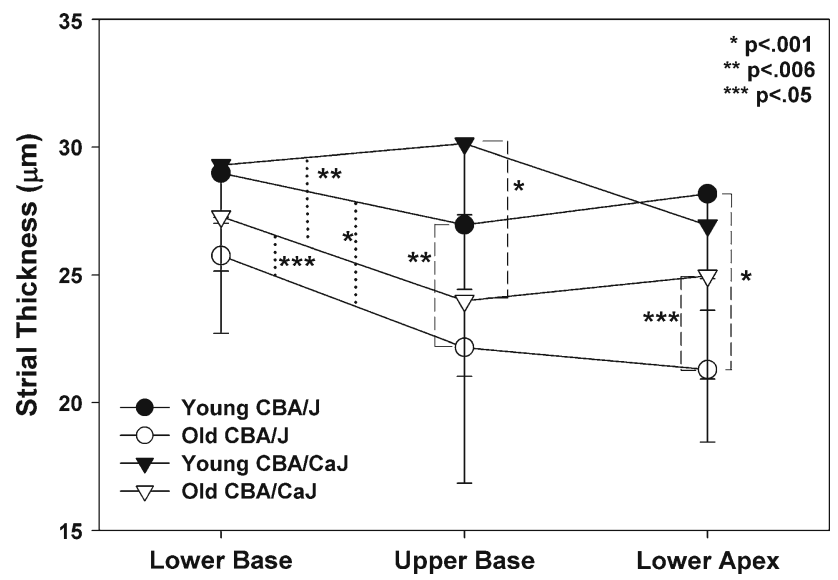

FIG. 12. Mean (-SD) strial thickness versus cochlear location for young and old $\mathrm{CBA} / \mathrm{J}$ and $\mathrm{CBA} / \mathrm{CaJ}$ mice. Significant differences were found by strain and age. Both strains showed strial thinning with age, but old $\mathrm{CBA} / \mathrm{Ca}$ ) mice tended toward a thicker stria than old $\mathrm{CBA} / \mathrm{J}$. $P$ values are from Bonferroni multiple comparisons tests following two-way ANOVA.

CaJ (Figs. 9 and 10) could not clearly be explained by differential marginal cell survival.

We tested the ability of strial marginal cell density in the cochlear upper basal turn to predict the EP. As shown in Figure 15A and D, marginal cell density correlates with the EP in $\mathrm{CBA} / \mathrm{CaJ}$ mice and appears to account for about $16 \%$ of EP variance. Neither of the two other major strial cell types (basal and intermediate cells) showed significant variation by strain, or any significant correlation with EP (not shown).

\section{Spiral ligament histologic correlates of EP reduction}

We previously showed that thinning of the ligament correlates with EP decline in old mice of some strains

FIG. 13. A Mean (-SD) number of capillaries per strial profile versus cochlear location for young and old $\mathrm{CBA} / \mathrm{J}$ and $\mathrm{CBA} / \mathrm{CaJ}$. Old CBA/CaJ showed significantly greater capillary loss, yet the magnitude of loss was $<20 \%$. B Distribution of strial capillary sizes across all animals, grouped by strain and age. Each symbol represent the proportion of all capillaries falling within a $5 \mu \mathrm{m}$ diameter range $(0-$ $5,6-10$, etc.). Numbers in parentheses are the number of capillaries measured. For young mice of both strains, essentially all capillaries had diameters of $10 \mu \mathrm{m}$ or less, and appeared uniformly distributed across this range. With age, most animals showed a redistribution of capillary sizes to favor diameters $5 \mu \mathrm{m}$ or smaller. Old $\mathrm{CBA} / \mathrm{CaJ}$ females alone (arrow) also featured a notable fraction of capillaries $(\sim 11 \%)$ with diameters $>10 \mu \mathrm{m}$. C Re-plot of data from B normalized using 'young' data to show the change in distribution of capillary size with age. Note decrease in proportion of capillaries with diameters of $6-10 \mu \mathrm{m}$ for all groups, but less pronounced in CBA/ CaJ. Arrows highlight qualitatively different redistribution of capillary size in old $\mathrm{CBA} / \mathrm{CaJ}$ females, including a gain in the fraction of large capillaries. $P$ values in $\mathbf{A}$ are from Bonferroni multiple comparisons tests following two-way ANOVA.
(Ohlemiller et al. 2006, 2009). We therefore compared ligament thickness by strain and age in $\mathrm{CBA} / \mathrm{J}$ and $\mathrm{CBA} / \mathrm{CaJ}$. Both young and old $\mathrm{CBA} / \mathrm{J}$ mice showed a significantly thicker ligament than their $\mathrm{CBA} / \mathrm{CaJ}$ counterparts (Fig. 16). Moreover, ligament thickness in $\mathrm{CBA} / \mathrm{J}$ was surprisingly stable with age. Potential thickening of the ligament with age in CBA/ $\mathrm{CaJ}$ suggested by Figure 16 was not significant. No gender effects were found (not shown).

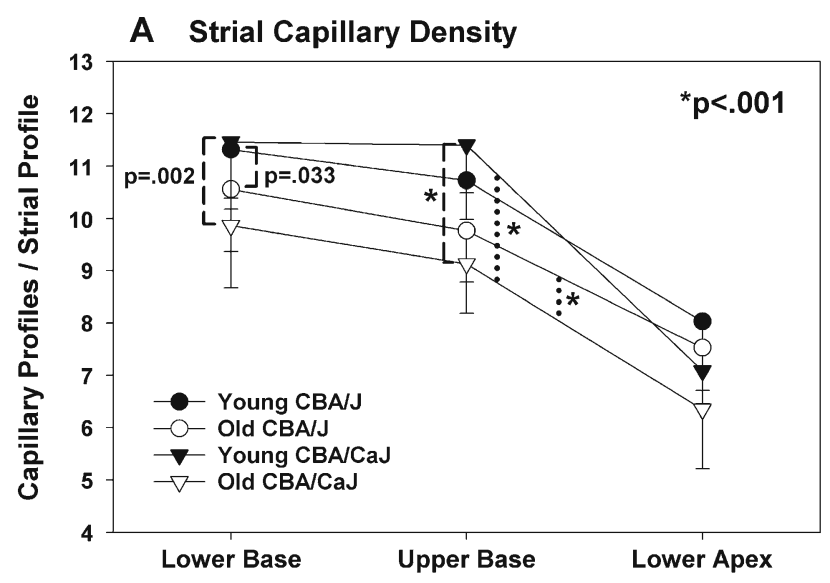

B Distribution of Strial Capillary Size

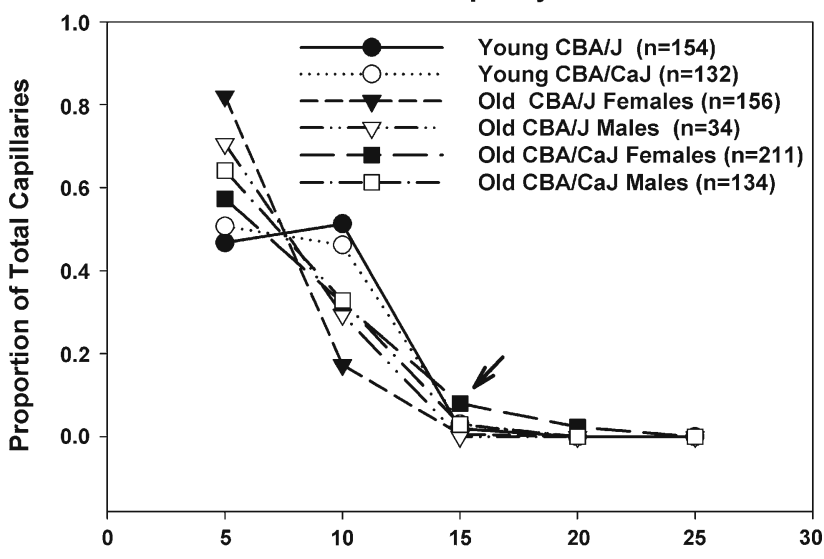

C Change in Capillary Size Distribution with Age

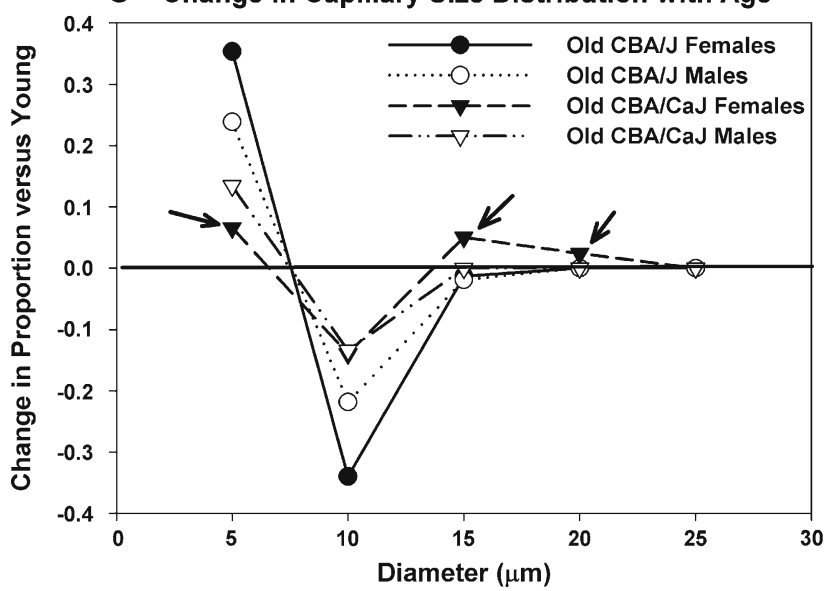




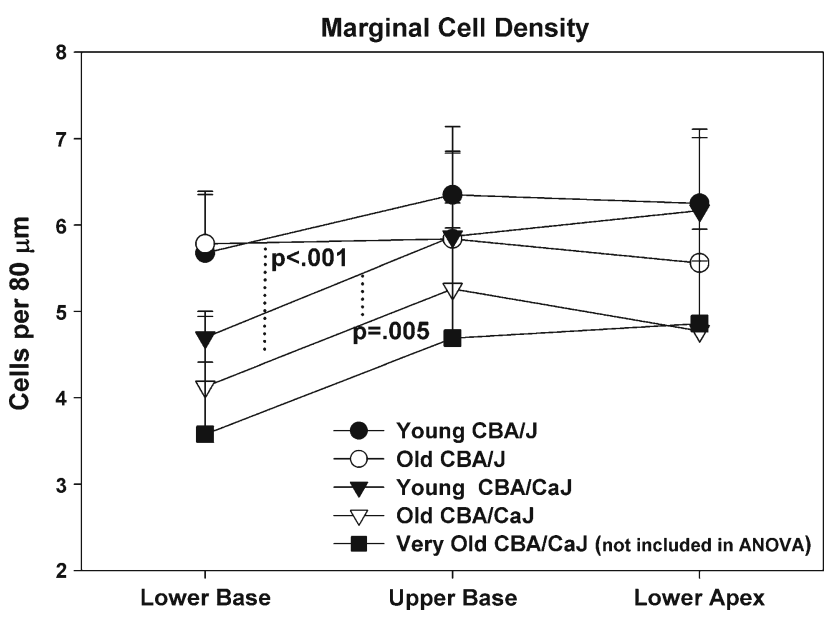

FIG. 14. Mean (+SD) strial marginal cell density at three cochlear locations by strain and age. Young $\mathrm{CBA} / \mathrm{J}$ mice tended toward more marginal cells than young $\mathrm{CBA} / \mathrm{CaJ}$, and sustained no significant loss with age. Old CBA/Cal showed significant loss of marginal cells, particularly in the lower cochlear base, with no clear effect of gender (not shown). $P$ values are from Bonferroni multiple comparisons tests following two-way ANOVA.

\section{Loss of outer sulcus cells/root cells in CBA/CaJ}

No prominent strain effects were found in the density of any type of ligament fibrocyte (data not shown). Close examination of the ligament, however, revealed a remarkable difference between $\mathrm{CBA} / \mathrm{J}$ and $\mathrm{CBA} /$ $\mathrm{CaJ}$. In the cochlear upper base, the region of ligament between organ of Corti and spiral prominence that is normally bordered by outer sulcus cells often contained few of these. Instead, there often appeared deep indentations or voids, suggestive of the loss of outer sulcus cells and root processes (see arrows in Figs. 11 and 17A). Cell counts (Fig. 18A) confirmed that $\mathrm{CBA} / \mathrm{J}$ mice retain more OSCs throughout life in both lower and upper cochlear base, and that only CBA/CaJ mice show loss of these cells in the upper base. The proportion of sections showing ligament indentations or voids also was significantly increased only in the cochlear upper base of old CBA/CaJ (Fig. 18B), where it appeared in the majority of sections. The severity of outer sulcus cell anomalies was not correlated with either EP (Fig. 15B) or thresholds (not shown).

The OSCs most affected appeared to be those lying more superior in the ligament, immediately below the spiral prominence (Figs. 11 and 17A), and may represent a specific population. We further noted that these were most likely to lie in the zone where Claudius cells and spiral prominence epithelial cells typically meet in $\mathrm{CBA} / \mathrm{J}$ cochleas, leaving no OSCs directly exposed to endolymph. In Figure 17, the point of termination of Claudius cells abutting the spiral ligament is compared in example old $\mathrm{CBA} / \mathrm{CaJ}$ and $\mathrm{CBA} / \mathrm{J}$ mice (compare points marked by arrowheads in Figure 17A, B). In the
$\mathrm{CBA} / \mathrm{CaJ}$, a thin Claudius cell process ends well inferior to a spiral prominence epithelium that follows the outline of the void left by missing OSCs and their root processes. In the $\mathrm{CBA} / \mathrm{J}$, a more expansive network of Claudius cells clearly ends at the thin line of cells marking spiral prominence. Basal-apical variation in the extent of 'exposure' to endolymph of OSCs has been reported as a normal feature of gerbils and guinea pigs (Duvall 1969; Spicer et al. 1996). It was our impression, however, that these cells are less often exposed in $\mathrm{CBA} / \mathrm{J}$ than in $\mathrm{CBA} / \mathrm{CaJ}$, even when young animals are compared.

\section{DISCUSSION}

We show that two intensively used 'good hearing' inbred mouse strains, $\mathrm{CBA} / \mathrm{J}$ and $\mathrm{CBA} / \mathrm{CaJ}$, differ in hearing sensitivity and cochlear pathology beginning around one year of age. Despite similar names and generally similar hearing characteristics for the first year, these two strains appear to model different forms of presbycusis. The $>80$ year span over which these strains have diverged (Fox et al. 1997) has been ample time for the accumulation of over 2,200 known genetic differences, including at least 41 non-synonymous exonic base changes (Bult et al. 2008). These or other polymorphisms must alter qualitatively the trajectory of cochlear aging. Key qualitative differences that set $\mathrm{CBA} / \mathrm{CaJ}$ apart from $\mathrm{CBA} / \mathrm{J}$ with age (summarized in Table 1) include EP decline, loss of strial marginal cells, and loss of outer sulcus cells in CBA/CaJ. These do not occur to a significant degree in $\mathrm{CBA} / \mathrm{J}$ mice, irrespective of gender, at any time in a typical lifespan.

\section{$\mathrm{CBA} / \mathrm{CaJ}$ versus $\mathrm{CBA} / \mathrm{J}$}

We agree with a previous assessment (Sha et al. 2008) that $\mathrm{CBA} / \mathrm{J}$ mice most closely approximate sensory presbycusis. The loss of predominantly outer hair cells in both base and apex (Fig. 4), also described by Sha et al. (2008), reasonably corresponds with the pattern of threshold shifts with age in $\mathrm{CBA} / \mathrm{J}$. According to our cell counts, old CBA/CaJ mice retain more OHCs than $\mathrm{CBA} / \mathrm{J}$, so that they cannot simply represent a more extreme version of the same aging model. We know of no other study that has specifically examined hair cell density in old CBA/CaJ mice. Previous studies have mixed $\mathrm{CBA} / \mathrm{J}$ and $\mathrm{CBA} / \mathrm{CaJ}$ (Spongr et al. 1997) or used other CBA/Ca substrains (Li 1992; Li and Hultcrantz 1994).

Comparative patterns of spiral ganglion cell loss in $\mathrm{CBA} / \mathrm{J}$ and $\mathrm{CBA} / \mathrm{CaJ}$ mice are nearly the inverse of their patterns of hair cell loss. That is, CBA/CaJs lose fewer OHCs than $\mathrm{CBA} / \mathrm{J}$, but more neurons, at both 

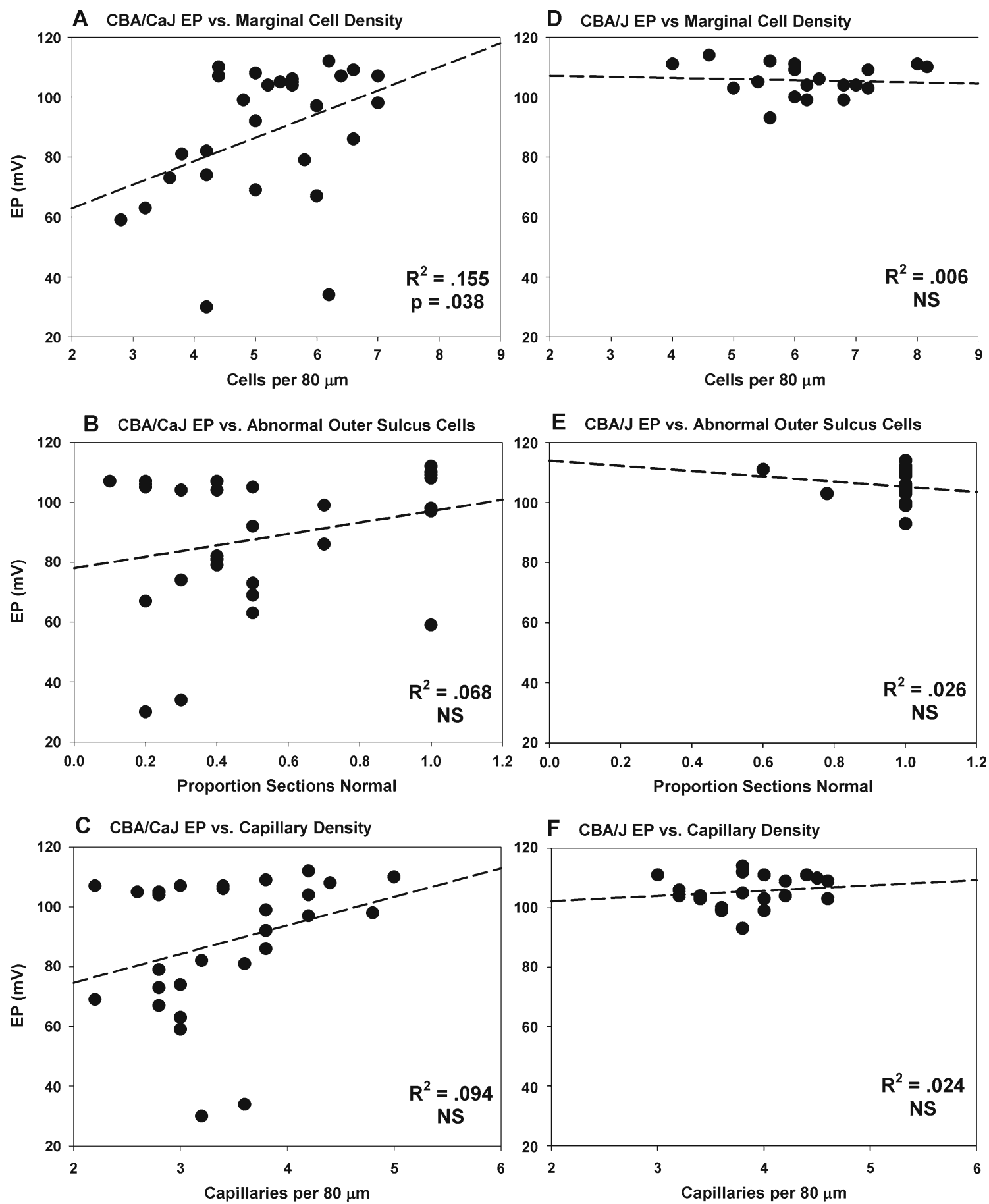

FIG. 15. Scatter plots of three anatomic metrics in the upper basal turn (marginal cell density, OSC abnormality, strial capillary density) versus basal turn EP for CBA/CaJ (A-C) and CBA/J $(\mathbf{d}-\mathbf{f})$. Only marginal cell density in CBA/CaJ was significantly correlated with EP.

apical and basal ends of the cochlea (Figs. 4 and 5). Complementary loss of different cell types may help explain why the two strains show similar patterns of low frequency hearing loss with age (Figs. 1 and 3). Alternatively, of course, the rate of low frequency hearing loss may reflect a common degeneration of some other cell or structure we did not quantify. Since neuronal loss in CBA/CaJ appeared to outpace inner hair cell loss (compare Figs. 4 and 5), this loss was likely a combination of primary and secondary loss. The pattern of accelerated neuronal loss in both base and apex matches a trend noted for humans (Felder and Schrott-Fischer 1995). To our knowledge, the present study is the first suggesting gender bias in neuronal loss.

While CBA/CaJ mice lost fewer OHCs in the lower base than $\mathrm{CBA} / \mathrm{J}$, there was some loss. We therefore cannot say that hair cell loss played no role in 


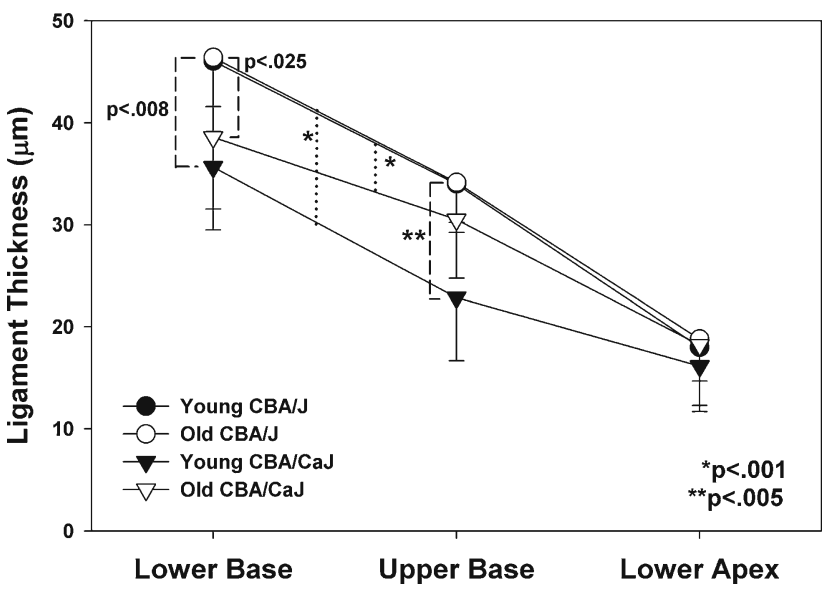

FIG. 16. Mean (-SD) spiral ligament thickness versus cochlear location for young and old $\mathrm{CBA} / \mathrm{J}$ and $\mathrm{CBA} / \mathrm{CaJ}$ mice. Significant differences were found by strain, so that $\mathrm{CBA} / \mathrm{CaJ}$ mice showed a thinner ligament, particularly in the basal half of the cochlea. $P$ values are from Bonferroni multiple comparisons tests following two-way ANOVA.

progressive high frequency threshold shifts. It would appear more correct to say that $\mathrm{CBA} / \mathrm{CaJ}$ mice add other forms of presbycusis to the sensory form displayed by $\mathrm{CBA} / \mathrm{J}$. Presently, no aging mouse model that has been well described remains free of significant hair cell loss over the normal life span (Spongr et al. 1997; Willott et al. 1998; Ohlemiller and Gagnon 2004a; Ohlemiller et al. 2008; Sha et al. 2008). Unlike spiral ganglion and stria vascularis, which possess redundant capacity, and for which moderate degeneration can apparently be tolerated without hearing loss (Schulte and Schmiedt 1992; El-Badry and McFadden 2009; Kujawa and Liberman 2009), OHCs are not present in excess. The predominant cochlear aging mode for mice may be sensory presbycusis, with strial and neural presbycusis added in some strains.

Threshold changes at high frequencies in both $\mathrm{CBA} / \mathrm{J}$ and CBA/CaJ appear sexually dimorphic, with females showing more rapid hearing loss than males by 15 or 24 months, respectively (Fig. 3). In this regard, our data seem to depart from a previous study indicating that $\mathrm{CBA} / \mathrm{CaJ}$ males sustain more rapid high frequency hearing loss (Henry 2004). At ages ranging 9-24 months, however, we likewise find poorer hearing in males, so that there appear to be two gender patterns over the CBA/CaJ lifespan. The oldest CBA/CaJ mice examined in the Henry (2004) study, 350 days of age, fell within a window that favors females in our data as well, and Henry would have missed a later transition. Notably, our data bring $\mathrm{CBA} / \mathrm{J}$ and $\mathrm{CBA} / \mathrm{CaJ}$ into register with another trend noted by Henry, namely that C57BL/ $6 \mathrm{~J}$ mice also feature more rapid hearing loss in females. CBA and B6 mice may not mimic a broadly supported trend in humans, whereby males fare more poorly with age (Jerger et al. 1993). However, they may usefully model the human phenomenon of accelerated hearing loss in females after menopause (Hederstierna et al. 2007) suggested to reflect loss of the protective effects of estrogen. Unfortunately, we know of only one estimate of age at menopause in mice, universally placing this event at 12-14 months (Silver 1995). It would be of interest to know whether the $\sim 9$-month strain difference in the age at which male and female thresholds diverge (Fig. 3) reflects a later age at menopause in CBA/CaJ. Gender effects on thresholds

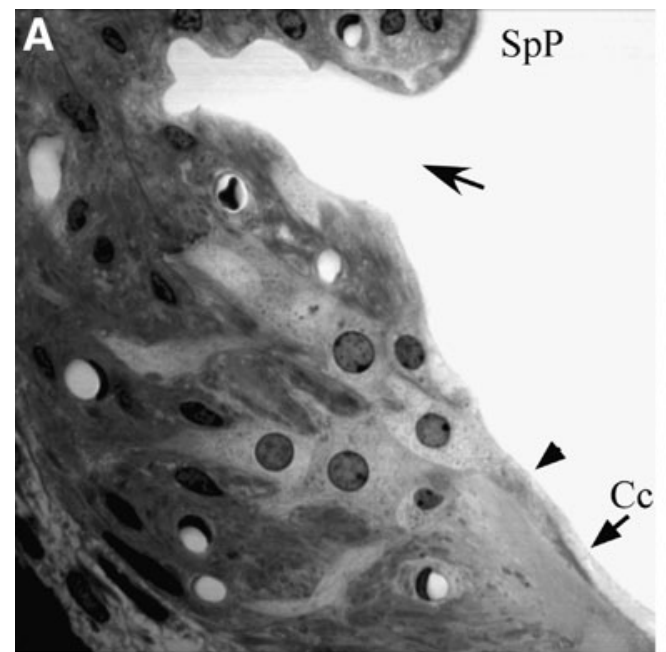

CBA/CaJ 34 mo Female 73 mV

FIG. 17. Example lateral wall of the cochlear upper basal turn in an old CBA/Cal female (A same animal as in Fig. 11A) and an old CBA/J female (B). Age and EP in each mouse are shown. The two images have been aligned to emphasize difference in survival of outer sulcus cells/root cells in the region just below spiral prominence (compare locations at large arrows). Potentially related was a difference in the

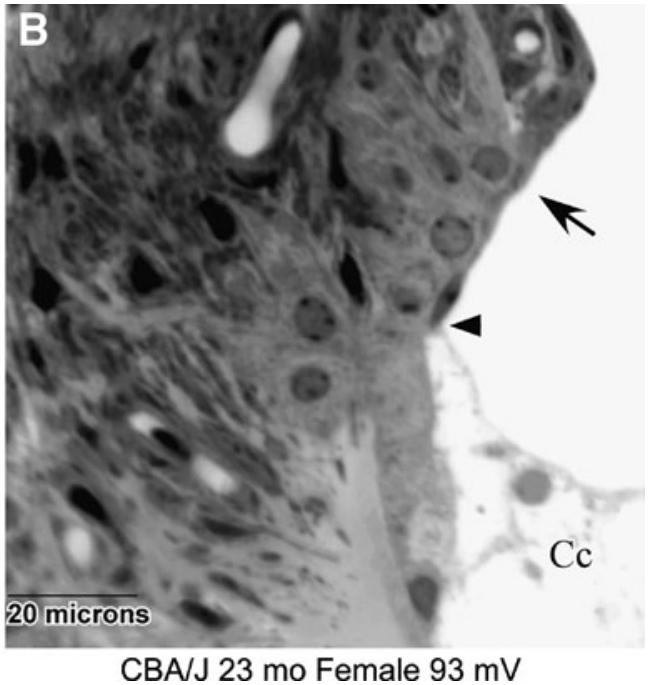

extent of coverage of OSCs at this location by spiral prominence epithelial cells. In CBA/J mice, the cells of spiral prominence ( $S p P$ ) more often contact Claudius cells $(C c)$ of the organ of Corti. Small arrowheads in each panel denote the apparent end of Claudius cell processes, leaving more OSCs exposed to endolymph in the CBA/ CaJ. 

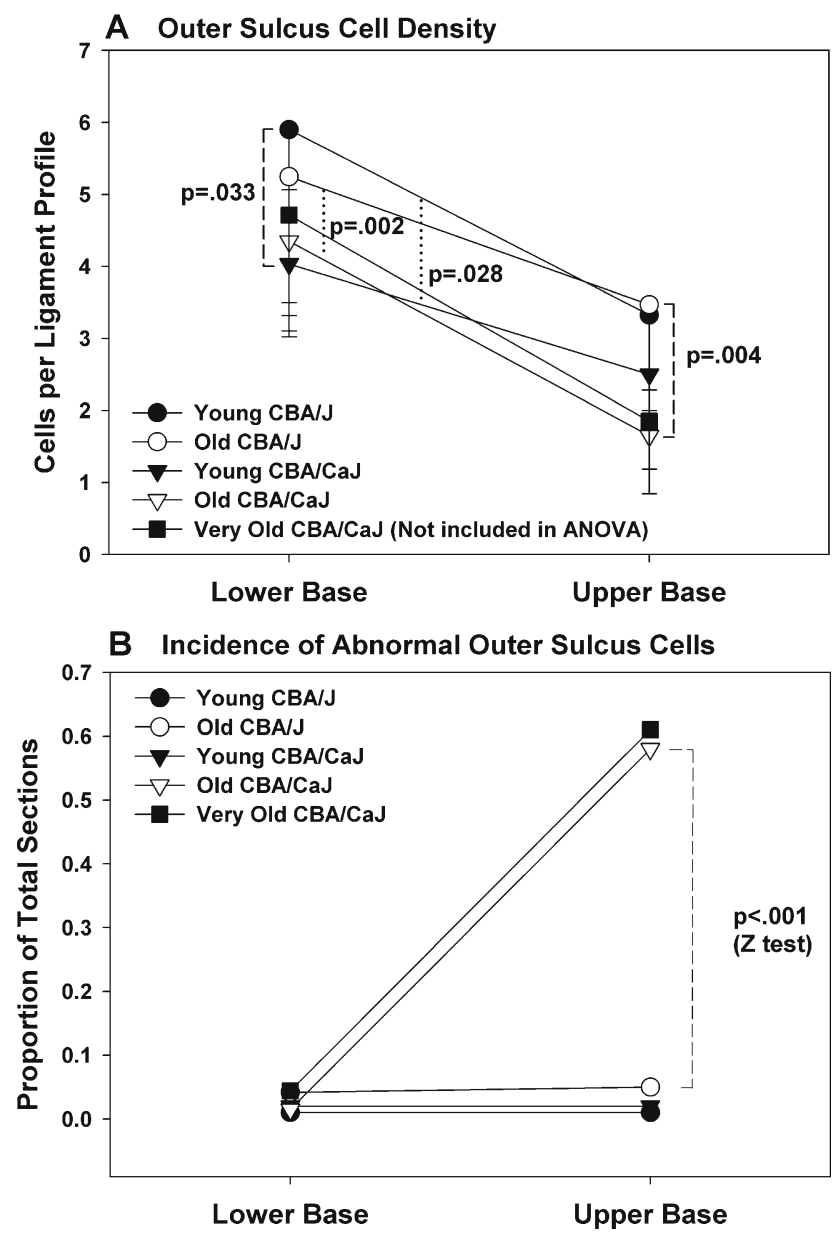

FIG. 18. A Mean(-SD) outer sulcus cell density in the upper and lower basal turn of young and old CBA/J and CBA/CaJ mice. CBA/CaJ mice show fewer of these cells, irrespective of age. B Incidence of abnormal OSC/root cell profiles by strain and age. Uniquely in old $\mathrm{CBA} / \mathrm{CaJ}$ mice, over $60 \%$ of sections exhibited indentations or voids in spiral ligament suggestive of $\mathrm{OSC} /$ root cell loss. $P$ values are in $\mathbf{A}$ from Bonferroni multiple comparisons tests following two-way ANOVA. in old CBA/CaJ parallel two anatomic trends. First, loss of cochlear neurons appears more pronounced in old females than in males (Fig. 5). Second, EP decline is significantly greater in females (Figs. 9 and 10). Therefore, neuronal loss and EP decline in CBA/CaJ may both be modulated by sex hormones or other gender-related characteristics (see below).

We cannot, of course, be sure that we have identified the essential cellular differences between aging $\mathrm{CBA} / \mathrm{J}$ and $\mathrm{CBA} / \mathrm{CaJ}$ that account for their threshold differences. We only sampled cochleas at fixed locations, although this strategy has proven successful in the past. The usual caveat - that cell counts need not correspond to cell functionality - must be injected. We found no clear anatomic correlate for more rapid hearing loss in female $\mathrm{CBA} / \mathrm{J}$ mice. In $\mathrm{CBA} / \mathrm{CaJ}$, EP variation accounted for only $30 \%$ of threshold variation at most, and no clear pattern by gender was identified for marginal cell loss. Moderate loss of outer sulcus cells in the upper base of $\mathrm{CBA} / \mathrm{CaJ}$ could certainly affect both EP and threshold (see below), but we detected no contribution to either EP decline or threshold elevation. Finally, we could not show correlation between neuronal density and thresholds in CBA/CaJ, and thus could not demonstrate that greater neuronal loss in old CBA/ CaJ females helps explain their more severe hearing loss. Most evidence indicates that only substantial neuronal loss is manifested in behaviorally or physiologically determined threshold shifts (El-Badry and McFadden 2009; Kujawa and Liberman 2009). Nevertheless, the $>50 \%$ loss of neurons exhibited in the lower base of old CBA/CaJ mice may be sufficient.

\section{Correlates of EP decline in CBA/CaJ}

Comparison with $\mathrm{CBA} / \mathrm{J}$ revealed several properties of cochlear lateral wall in old CBA/CaJ mice that have been linked to explicit, or suggested, EP decline.

TABLE 1

\begin{tabular}{|c|c|c|}
\hline \multicolumn{3}{|c|}{ Comparison of features in aging $\mathrm{CBA} / \mathrm{J}$ and $\mathrm{CBA} / \mathrm{CaJ}$ cochleae } \\
\hline Feature & Similarities & Differences \\
\hline Thresholds & Similar loss at low frequencies & $\begin{array}{l}\text { CBA/CaJ show greater loss at high } \\
\text { frequencies }\end{array}$ \\
\hline Thresholds by gender & \multicolumn{2}{|l|}{ Females more susceptible than males } \\
\hline Hair cell loss & \multirow[t]{3}{*}{ Similar IHC loss } & $\mathrm{CBA} / \mathrm{J}$ show more $\mathrm{OHC}$ loss \\
\hline Neuronal loss & & CBA/CaJ show more loss \\
\hline EP by age & & Only CBA/CaJ show EP decline \\
\hline Strial capillaries ${ }^{\mathrm{a}}$ & \multirow[t]{2}{*}{ Increased fraction of capillaries $<5 \mu \mathrm{m}$ with age } & $\begin{array}{l}\text { CBA/CaJ females show increase in } \\
\text { fraction of capillaries }>10 \mu \mathrm{m} \text { with age }\end{array}$ \\
\hline Strial marginal cells & & Only CBA/CaJ show significant loss \\
\hline Strial intermediate, basal cells ${ }^{\mathrm{a}}$ & \multirow[t]{2}{*}{ Similar density, little change with age } & \\
\hline Spiral ligament & & Thinner in $\mathrm{CBA} / \mathrm{CaJ}$ \\
\hline Ligament types I, II, IV fibrocytes ${ }^{\mathrm{a}}$ & \multirow[t]{2}{*}{ Similar density, little change with age } & \\
\hline Outer sulcus cells & & Only CBA/CaJ show significant loss \\
\hline
\end{tabular}

${ }^{\mathrm{a}}$ Based on analysis of upper base 


\section{Strial thickness}

Strial thinning is a commonly reported aspect of cochlear aging (Kusunoki et al. 2004; Suzuki et al. 2006; Ishiyama et al. 2007), although it is often not clear when thinning is functionally meaningful. However, differences in strial thickness in our material (Fig. 12) actually favor $\mathrm{CBA} / \mathrm{CaJ}$, a trend that may reflect pathology not evident at the light microscope level.

\section{Microvascular changes}

Reduced capillary density, reduced capillary size, and changes in capillary structure have all been implicated in real or potential EP decline (Johnsson and Hawkins 1972; Gratton and Schulte 1995; Gratton et al. 1996; Thomopoulos et al. 1997). As we have noted however (Ohlemiller et al. 2006), neither $>50 \%$ reductions in strial capillary density (Di Girolamo et al. 2001), nor more than doubling of capillary basement membrane thickness in C57BL/6 mice promote EP decline (Lang et al. 2002). By contrast, capillary loss in $\mathrm{CBA} / \mathrm{CaJ}$ mice is generally less than 20\% (Fig. 13A). Probably more important was strial capillary size redistribution with age (Fig. $13 \mathrm{~B}, \mathrm{C}$ ). The fact that $\mathrm{CBA} / \mathrm{J}$ mice showed the most pronounced shift toward smaller capillary sizes renders this an unlikely key factor in EP decline. Greater retention of larger capillaries in old $\mathrm{CBA} / \mathrm{CaJ}$ - and particularly the increase in the fraction of the largest capillaries in old female $\mathrm{CBA} / \mathrm{CaJ}$ - may be more significant. We previously noted a similar trend in old female BALB/c mice, in which average capillary size was greater in mice showing EP decline (Ohlemiller et al. 2006). A shift toward larger strial capillaries may point to another process that contributes to $\mathrm{EP}$ reduction, or perhaps to a compensatory response. Local stress responses may sense EP reduction, ion imbalance, or hypoxia, and increase capillary size in response. Abnormally large strial capillaries may emerge as an anatomic marker for the presence of EP decline.

\section{Spiral ligament thickness and fibrocyte density}

The finding that a relatively thin spiral ligament in CBA/CaJ (Fig. 16) coincides with a tendency toward EP decline mirrors a trend in two other mouse models we have described (Ohlemiller et al. 2006, 2009). $\mathrm{BALB} / \mathrm{c}$ mice in particular combine somewhat low marginal cell density and a thin spiral ligament with slightly reduced EP $(\sim 10 \mathrm{mV})$ from an early age, and these become more pronounced with time. There is disagreement about the existence of any causal linkand direction thereof-between pathology of the stria and spiral ligament (e.g., Hequembourg and Liberman 2001; Spicer and Schulte 2002; Wu and Marcus 2003; Ishiyama et al. 2007). Aging appears reliably associated with progressive reduction in ligament volume and loss of fibrocytes in both humans and animals (Wright and Schuknecht 1972; Spicer and Schulte 2002; Kusunoki et al. 2004; Ishiyama et al. 2007). However, comparison of the extent of ligament degeneration and strial pathology across multiple inbred mouse models suggests that these need not be closely related (Ohlemiller 2009). Disruption of $\mathrm{K}^{+}$flux through the ligament can reduce the EP, but it is not clear this promotes strial degeneration (e.g., Minowa et al. 1999). A thin spiral ligament early in life may signal a developmental process that also limits marginal cell density, and promotes eventual EP decline.

\section{The role of gender in hearing and EP decline}

Our data suggest that $\mathrm{CBA} / \mathrm{CaJ}$ mice begin life with fewer marginal cells than CBA/J (Fig. 14), then undergo further marginal cell loss with age. CBA/J mice, by contrast, do not show significant loss of marginal cells over their typical life span. Primary loss or dysfunction of marginal cells is emerging as the most frequently cited basis of EP decline in humans (Pauler et al. 1988; Schuknecht and Gacek 1993) and animal models (Spicer and Schulte 2005a; Ohlemiller et al. 2006; Ohlemiller 2009). That said, marginal cell loss did not seem to explain prominent gender differences in $\mathrm{CBA} / \mathrm{CaJ}$, and gender effects on marginal cell function must be considered. The idea that estrogen impacts strial marginal cell operation is supported by the literature (Konig et al. 2008; Motohashi et al. 2010). Interestingly, the effect appears to be one of inhibition (Lee and Marcus 2001). Inhibition of strial ion transport coincides with a suggested overall protective effect of estrogen on sensory cells (Vina et al. 2005; Charitidi et al. 2009). It is conceivable that effects of estrogen in females partly explain both reduction of the EP after 1 year and the acceleration of hearing loss after 2 years (that is, after menopause). Alternatively, sex-related differences other than strictly hormonal processes may underlie the gender trends we observe (Willott 2009). The apparent gender-skewing of EP decline in aging CBA/ $\mathrm{CaJ}$ matches a trend suggested for humans (Gates et al. 1999; Gates and Mills 2005), so that the underlying mechanisms merit further study.

\section{Loss of outer sulcus cells in CBA/CaJ}

Loss of outer sulcus cells in CBA/CaJ adds a new twist to how threshold sensitivity and EP generation may be altered in these mice. In this and other mouse models we have examined, we have interpreted reduced marginal cell density as an indication that critical marginal cell functions in generating the EP are impaired. We suppose-but have yet to show-that fewer, larger, marginal cells maintain fewer critical 
pumps, transporters, and channels (Gratton et al. 1997), or alter the critical 'stoichiometry' of these among strial cell types (Diaz et al. 2007). We have not proposed or observed that marginal cell degeneration leaves exposed intermediate cells or alters the ion barrier of scala media. Published descriptions of aging gerbils, which also appear to model EP decline originating with marginal cell pathology, are likewise consistent with the maintenance of a continuous marginal cell covering. By contrast with marginal cells, outer sulcus cells and the root processes they compose project deep into the ligament (Duvall 1969; Spicer et al. 1996). OSC loss seems likely to uncover cells not normally exposed to endolymph, and not expressing tight junctions. OSC loss therefore probably violates the integrity of scala media. Sufficient loss of outer sulcus cells would act as an uncontrolled ion shunt, lowering the EP and reducing $\mathrm{K}^{+}$currents through hair cells. While this certainly could explain some characteristics of $\mathrm{CBA} / \mathrm{CaJ}$ mice, we could not link the severity of OSC degeneration to hearing loss. The spatially delimited pattern of OSC loss in these mice may reduce its impact on hearing. As we noted, the OSCs most affected appeared to be those lying where Claudius cells and spiral prominence epithelial cells typically meet, and appeared less often exposed in $\mathrm{CBA} / \mathrm{J}$ than in $\mathrm{CBA} / \mathrm{CaJ}$. However, it has not been suggested that exposure of some OSCs represents a form of pathology. For now, loss of outer sulcus cells joins a long list of noted age-related cochlear changes-including capillary loss, ligament fibrocyte loss, limbus fibrocyte loss, organ of Corti supporting cell loss, clumping of neuronal cell bodies, pillar cell anomalies, and changes in Reissner's membrane (Cohen et al. 1990; Adams and Schulte 1997; Hequembourg and Liberman 2001; Ohlemiller and Gagnon 2004a, 2004b) - whose significance for the incidence and severity of presbycusis is not clear.

\section{The value of the $n$th aging model}

Investigators in human presbycusis and its animal models must continually apply optimism that if we examine enough cases and models, a finite number of patterns will emerge. Even if a manageable number of patterns do emerge, they will certainly reflect a much larger set of genetic and environmental causes. Nevertheless, focusing on patterns may point the way to a manageable number of therapeutic targets. Unfortunately, the number of patterns divined from human temporal bones is discouragingly large (for an excellent review, see Nelson and Hinojosa 2006). Most discrepancies derive from the degree of presbycusis attributed to pathology of neurons versus hair cells versus strial cells. An implicit theme that runs through
Schuknecht's work (Schuknecht 1993; Schuknecht and Gacek 1993) is that these cells and structures can degenerate independently. In fact, these are rarely encountered in isolation, and temporal bone analyses rarely resolve how much hearing loss is attributable to each. The significance of their posited independent degeneration lies in its implications for underlying mechanisms. Invariant co-degeneration of neurons, hair cells, and strial cells (to an extent that all contribute to hearing loss) would suggest different disease mechanisms than would co-degeneration of only subsets of these. Just how much and what type of lateral wall degeneration is incompatible with a normal EP is currently best determined from comparisons of mouse models. Since the EP must be measured to 'diagnose' strial presbycusis, few models can be considered adequately characterized.

\section{ACKNOWLEDGMENTS}

This work was supported by NIH R01 DC03454, DC08321 (KKO), P30 DC04665 (R. Chole) and Washington University Medical School Department of Otolaryngology.

\section{REFERENCES}

Adams JC, Schulte BA (1997) Histopathologic observations of the aging gerbil cochlea. Hear Res 104:101-111

Bohne BA, Gruner MM, Harding GW (1990) Morphological correlates of aging in the chinchilla cochlea. Hear Res 48:79-91

Bult CJ, Eppig JT, Kadin JA, Richardson Je, Blake JA (2008) The mouse genome database (MGD): mouse biology and model systems. Nucleic Acids Res 36:D724-D728

Charitidi K, Meltser I, Tahera Y, Canlon B (2009) Functional responses of estrogen receptors in the male and female auditory system. Hear Res 252:71-78

Cohen GM, PARK JC, Grasso JS (1990) Comparison of demyelination and neural degeneration in spiral and Scarpa's ganglion of C57BL/6 mice. J Electron Microsc Tech 15:165-172

Covell WP, Rogers JB (1957) Pathologic changes in the inner ear of senile guinea pigs. Laryngoscope 67:118-129

Di Girolamo S, Quaranta N, Picciotti P, Torsello A, Wolf F (2001) Age-related histopathological changes of the stria vascularis: an experimental model. Audiology 40:322-326

Diaz RC, Vazquez Ae, Dou H, Wei D, Cardell El, Lingrel J, Shull GE, Doyle KJ, YамоAн EN (2007) Conservation of hearing by simultaneous mutation of Na, K-ATPase and NKCCl. J Assoc Res Otolaryngol 8:422-434

Duvall AJ (1969) The ultrastructure of the external sulcus in the guinea pig cochlear duct. Laryngoscope 79:1-29

EL-BADRY MM, McFAdDEN SL (2009) Evaluation of inner hair cell and nerve fiber loss as sufficient pathologies underlying auditory neuropathy. Hear Res 255:84-90

Erway Lc, Willott JF, Archer JR, Harrison DE (1993) Genetics of age-related hearing loss in mice: I. Inbred and F1 hybrid strains. Hear Res 65:125-132

Felder E, Schrott-Fischer A (1995) Quantitative evaluation of myelinated nerve fibers in cochlea of humans with age-related high-tone hearing loss. Hear Res 91:19-32 
Fernandez EA, Ohlemiller KK, Gagnon PM, Clark WW (2010) Protection against noise-induced hearing loss in young $\mathrm{CBA} / \mathrm{J}$ mice by low-dose kanamycin. J Assoc Res Otolaryngol 11:235-244

Fox RR, Witham BA, Neleski LA, (EDs.) 1997. Handbook of genetically standardized JAX mice. The Jackson Laboratory, Bar Harbor ME.

FrISINA RD (2009) Age-related hearing loss: ear and brain mechanisms. Ann NY Acad Sci 1170:708-717

Gates GA, Mills JH (2005) Presbycusis. Lancet 366:1111-1120

Gates GA, Couropmitree NN, Myers RH (1999) Genetic associations in age-related hearing thresholds. Arch Otolaryngol Head Neck Surg 125:654-659

Gratton MA, Schulte BA (1995) Alterations in microvasculature are associated with atrophy of the stria vascularis in quiet-aged gerbils. Hear Res 82:44-52

Gratton MA, Schmiedt RA, Schulte BA (1996) Age-related decreases in endocochlear potential are associated with vascular abnormalities in the stria vascularis. Hear Res 102:181-190

Gratton MA, Smyth BJ, Lam CF, Boettcher FA, Schmiedt RA (1997) Decline in the endocochlear potential corresponds to decreased $\mathrm{Na}$, K-ATPase activity in the lateral wall of quiet-aged gerbils. Hear Res 108:9-16

Hederstierna C, Hultcrantz M, Collins A, Rosenhall U (2007) Hearing in women at menopause: prevalence of hearing loss, audiometric configuration and relation to hormone replacement therapy. Acta Otolaryngol 27:149-155

HenRY KR (1983) Ageing and audition. In: Willott JF (ed) The auditory psychobiology of the mouse. Thomas, Springfield, pp 470-494

HENRY KR (2004) Males lose hearing earlier in mouse models of lateonset age-related hearing loss; females lose hearing earlier in mouse models of early-onset hearing loss. Hear Res 190:141-148

HenRy KR, McGinn MD (1992) The mouse as a model for human audition. A review of literature. Audiology 31:181-189

Hequembourg S, Liberman MC (2001) Spiral ligament pathology: a major aspect of age-related cochlear degeneration in C57BL/6 mice. J Assoc Res Otolaryngol 2:118-129

Hirose K, Liberman MC (2003) Lateral wall histopathology and endocochlear potential in the noise-damaged mouse cochlea. J Assoc Res Otolaryngol 4:339-352

Ishivama G, Tokita J, Lopez I, Tang Y, Ishiyama A (2007) Unbiased stereological estimation of the spiral ligament and stria vascularis volumes in aging and Meniere's disease using archival human temporal bones. J Assoc Res Otolaryngol 8:8-17

Jagger DJ, NeVill G, Forge A (2010) The membrane properties of cochlear root cells are consistent with roles in potassium recirculation and spatial buffering. JARO 11:435-448

Jerger J, Chmiel R, Stach B, Spretnjak M (1993) Gender affects audiometric shape in presbycusis. J Am Acad Audiol 4:42-49

JoHnsson L-G, Hawkins JE (1972) Vascular changes in the human ear associated with aging. Ann Otol 81:364-376

Konig O, Ruttiger L, Muller M, Zimmermann U, Erdmann B, Kalbacher H, Gross M, Knipper M (2008) Estrogen and the inner ear: megalin knockout mice suffer progressive hearing loss. FASEB J 22:410-417

KujaWA SG, Liberman MC (2009) Adding insult to injury: cochlear nerve degeneration after 'temporary' noise-induced hearing loss. J Neurosci 29:14077-14085

Kusunoki T, Cureoglu S, Schachern Pa, Baba K, Karyia S, Paparella MM (2004) Age-related histopathologic changes in the human cochlea: a temporal bone study. Arch Otolaryngol Head Neck Surg 131:897-903

LANG H, Schulte BA, Schmiedt RA (2002) Endocochlear potentials and compound action potential recovery: functions in the C57BL/6J mouse. Hear Res 172:118-126
Lang H, Schulte BA, Schmiedt RA (2003) Effects of chronic furosemide treatment and age on cell division in the adult gerbil inner ear. J Assoc Res Otolaryngol 4:164-175

Lee JH, Marcus DC (2001) Estrogen acutely inhibits ion transport by stria vascularis. Hear Res 158:123-130

LI H-S (1992) Genetic influences on susceptibility of the auditory system to aging and environmental factors. Scand Audiol Suppl 36:1-39

Li H-S, Hultcrantz M (1994) Age-related degeneration of the organ of corti in two genotypes of mice. Oto Rhino Laryngol 56:61-67

Marcus DC, Chiba T (1999) $\mathrm{K}^{+}$and $\mathrm{Na}^{+}$absorption by outer sulcus epithelial cells. Hear Res 134:48-56

Minowa O, Ikeda K, Sugitani Y, Oshima T, Nakai S, Katori Y, Suzuki M, Furukawa M, Kawase T, Zheng Y, Ogura M, Asada Y, Watanabe K, Yamanaka H, Gotoh S, Nishi-Takeshima M, Sugimoto T, Kikuchi T, Takasaka T, Noda T (1999) Altered cochlear fibrocytes in a mouse model of DFN3 nonsyndromic deafnesss. Science 285:1408-1411

Motohashi R, Takumida M, Shimizu A, Konomi U, FujtTa K, Hirakawa K, Suzuki M, AnNiko A (2010) Effects of age and sex on the expression of estrogen receptor $\alpha$ and $\beta$ in the mouise inner ear. Acta Otolaryngol 130:204-214

Muller M, von Hunerbein K, Hoidis S, Smolders JWT (2005) A physiological place-frequency map of the cochlea in the CBA/J mouse. Hear Res 202:63-73

Nelson EG, Hinojosa R (2006) Presbycusis: a human temporal bone study of individuals with downward sloping audiometric patterns of hearing loss and review of the literature. Laryngoscope 116 (suppl 112):1-12

Ohlemiller KK (2006) Contributions of mouse models to understanding of age- and noise-related hearing loss. Brain Res 1091:89-102

OHLEmiller KK (2009) Mechanisms and genes in human strial presbycusis from animal models. Brain Res 1277:70-83

OHLEMILLeR KK, GAGNON PM (2004A) Cellular correlates of progressive hearing loss in 129 S6/SvEv mice. J Comp Neurol 469:377-390

Ohlemiller KK, GAGNON PM (2004B) Apical-to-basal gradients in age-related cochlear degeneration and their relationship to 'primary' loss of cochlear neurons. J Comp Neurol 479:103-116

Ohlemiller KK, GaGnon PM (2007) Genetic dependence of cochlear cells and structures injured by noise. Hear Res 224:34-50

OHLEMiller KK, Frisina RD (2008) Age-related hearing loss and its cellular and molecular bases. In: Schacht J, Popper AN, Fay RR (eds) Auditory trauma, protection, and repair. Springer, New York, pp 145-194

Ohlemiller KK, Lett JM, Gagnon PM (2006) Cellular correlates of age-related endocochlear potential reduction in a mouse model. Hear Res 220:10-26

Ohlemiller KK, Rybak Rice ME, Gagnon PM (2008) Strial microvascular pathology and age-associated endocochlear potential decline in NOD congenic mice. Hear Res 244:85-97

Ohlemiller KK, Rice MR, Lett JM, Gagnon PM (2009) Absence of strial melanin coincides with age associated marginal cell loss and endocochlear potential decline. Hear Res 249:1-14

Pauler M, Schuknecht HF, White JA (1988) Atrophy of the stria vascularis as a cause of sensorineural hearing loss. Laryngoscope 98:754-759

Sснаснт J, Hawkins JE (2005) Sketches of otohistory. Part 9: presby [a]cusis. Audiol Neuro-Otol 10:243-247

Schmiedt RA (2010) Chapter 2: The physiology of cochlear presbycusis. In: Gordon-Salant, S., Frisina, R.D., Popper, A.N., Fay, R.R., (Eds.), Springer handbook of auditory research. The Aging Auditory System, Vol. 34. Springer, New York. pp. 9-38.

Schuknecht HF (1974) Pathology of the ear, 1st edn. Harvard University Press, Cambridge

Schuknecht HF (1993) Pathology of the ear, 2nd edn. Lea and Febiger, Philadelphia 
Schuknecht HF, GACEk MR (1993) Cochlear pathology in presbycusis. Ann Otol Rhinol Laryngol 102:1-16

Schuknecht HF, Watanuki K, Takahashi T, Belal AA, Kimura RS, JonEs DD (1974) Atrophy of the stria vascularis, a common cause for hearing loss. Laryngoscope 84:1777-1821

Schulte BA, Schmiedt RA (1992) Lateral wall Na, K-ATPase and endodochlear potentials decline with age in quiet-reared gerbils. Hear Res 61:35-46

Sha S-H, Kanicki A, Dootz Ga, Talaska Ae, Halsey K, Dolan DF, Altschuler RA (2008) Age-related auditory pathology in the CBA/J mouse. Hear Res 243:87-94

SILVER LM (1995) Mouse genetics. Oxford, Oxford, UK

Spicer SS, SChulte BA (2002) Spiral ligament pathology in quietaged gerbils. Hear Res 172:172-185

SPICER SS, Schulte BA (2005A) Pathologic changes of presbycusis begin in secondary processes and spread to primary processes of strial marginal cells. Hear Res 205:225-240

SPICER SS, SCHUlte BA (2005B) Novel structures in marginal and intermediate cells presumably relate to functions of basal versus apical strata. Hear Res 200:87-101

Spicer SS, SAmuel S, Schulte BA (1996) The fine structure of spiral ligament cells relates to ion return to the stria and varies with place-frequency. Hear Res 100:80-100

Spongr VP, Flood DG, Frisina RD, Salvi RJ (1997) Quantitative measures of hair cell loss in CBA and C57BL/6 mice throughout their life span. J Acoust Soc Am 101:3546-3553

Suzuki T, Nomoto Y, Nakagawa T, Kuwahata N, Ogawa H, Suzuki Y, Iто J, Oмов K (2006) Age-dependent degeneration of the stria vascularis in human cochleae. Laryngoscope 116:18461850

Tarnowski BI, Schmiedt RA, Hellstrom LI, Lee FS, Adams JC (1991) Age-related changes in cochleas of Mongolian gerbils. Hear Res 54:123-134

Thomopoulos GN, Spicer SS, Gratton MA, Schulte BA (1997) Agerelated thickening of basement membrane in stria vascularis capillaries. Hear Res 111:31-41

Vina J, Borras C, Gambini J, Sastre J, Pallardo FV (2005) Why females live longer than males? Importance of the upregulation of longevity-associated genes by oestrogenic compounds. FEBS Lett 579:2541-2545

WiLlott JF (1991) Aging and the auditory system: anatomy, physiology, and psychophysics. Singular, San Diego

WiLLOTt JF (2001) Modulation of presbcusis: current status and future directions. Audiol Neuro-Otol 6:231-249

WiLlott JF (2009) Effects of sex, gonadal hormones, and augmented acoustic environments on sensorineural hearing loss and the central auditory system: insights from research on C57BL/6J mice. Hear Res 252:89-99

Willott JF, Turner JG, Carlson S, Ding D, Bross LS, Falls WA (1998) The BALB/c mouse as an animal model for progressive sensorineural hearing loss. Hear Res 115:162-174

Wright CG, Schuknecht HF (1972) Atrophy of the spiral ligament. Arch Otolaryngol 96:16-21

Wu T, Marcus DC (2003) Age-related changes in cochlear endolymphatic potassium and potential in CD-1 and CBA/CaJ mice. J Assoc Res Otolaryngol 4:353-362 